DOI 10.15290/cnisk.2021.02.11.03

EWA MAJ

https://orcid.org/0000-0002-7295-1759

Uniwersytet Marii Curie-Skłodowskiej w Lublinie

\title{
Obraz społecznych ruchów kobiet na łamach prasy dla katoliczek w Polsce międzywojennej ${ }^{1}$
}

\begin{abstract}
Streszczenie
Celem artykułu było ukazanie wybranych składników kultury organizacyjnej społecznych ruchów kobiet i ich odzwierciedlenia w prasie dla katoliczek w Polsce w latach 1918-1939. Prasa wyznaniowa stanowiła istotny segment produkcji wydawniczej, w której uwzględniono periodyki adresowane do kobiet. Prezentowała wartości narodowe i religijne, propagowała postawy czynnej obrony polskości i katolicyzmu przeciw zagrożeniu immoralizmem i kosmopolityzmem.

W przekazie prasowym społeczne ruchy katoliczek były prężne, zintegrowane, silnie oddziałujace na członkinie. Na ich całościowy obraz składały się dwa obrazy cząstkowe: instytucjonalne i personalne. $Z$ nich wynikało wyobrażenie Polki katoliczki i Matki-Polki, realizującej zadania apostolstwa świeckiego.

Słowa kluczowe: prasa wyznaniowa, ruchy społeczne, aktywność społeczna katoliczek, apostolstwo świeckie, kobiety w Polsce międzywojennej

\footnotetext{
Publikacja przygotowana/finansowana w ramach programu Ministra Nauki i Szkolnictwa Wyższego pod nazwa DIALOG w latach 2019-2021. Jest wynikiem udziału w projekcie badawczym pt. „Ośrodek badań historii kobiet”, nr 0016/DLG/2019/10.
} 


\title{
THE IMAGE OF THE WOMEN'S SOCIAL MOVEMENTS IN THE CATHOLIC PRESS IN THE INTERWAR POLAND
}

\begin{abstract}
The purpose of the article was to show some aspects of women's social movements and related press for Catholic women in the interwar Poland. Back then the religious press was an important part of publishing. Some of the papers were published directly for women. These periodicals were supporting national and religious values, were propagating the need to defend Poland and the Catholic faith against the immorality and cosmopolitism.

The social movements of Polish Catholic women were strong, integrated and influenced among their members. They were showing the ideal of women in the country - both Polish-Catholic and the "Polish-Mother" - who is considered a secular apostole.
\end{abstract}

Keywords: religious press, social movements, social activity of Catholics, secular apostole, women in the interwar Poland

\section{Wprowadzenie}

Ruchy społeczne kreuja nowe wartości, określaja nowe cele oraz przedkładaja zadania, które prowadzą do przekształcenia przestrzeni publicznej i sformowania nowych form organizacyjnych, by reprezentowały wspomniane wartości. Moga być źródłem przeobrażeń strukturalnych i personalnych zachodzacych w społeczeństwie. Uczestnicy tychże ruchów prezentuja projekty zmian, buduja sieci współdziałania wewnątrz i na zewnątrz struktury organizacyjnej, tworząc przestrzeń działań społecznych o wielokształtnej postaci. Ruchy społeczne powstają wskutek doznania niesprawiedliwości ekonomicznej, politycznej, prawnej. Na ogół maja oddolny charakter, tworząc krag ludzi niezadowolonych ze swojej sytuacji i określając program realizacji ich interesów. W chwili kreowania nowoczesnych ruchów kobiet na przełomie XIX i XX w. Polki katoliczki w sposób zwielokrotniony odczuwały niesprawiedliwość ze względu na narodowość, wierzenie religijne, płeć. Na ziemiach polskich doznawały skutków opresyjności państw zaborczych, nierówności prawnej, dyskryminacji wyznaniowej, wykluczenia politycznego, rygoryzmu tradycjonalistycznej obyczajowości. Poddawane były następstwom wyzysku ekonomicznego, ubóstwa materialnego, 
nierówności społecznych, niesprawiedliwości systemu prawnego i politycznego, braku poszanowania wolności osobistej. Podejmowały zatem działania na rzecz niwelacji upośledzenia, wchodząc do istniejacych struktur organizacyjnych (ugrupowań politycznych, stowarzyszeń społecznych) i/lub tworząc własne apolityczne bądź parapolityczne zrzeszenia. Zaangażowanie w praktyki społeczne, służace pobudzeniu aktywności kobiet, stanowi istotny problem badawczy, którego rozwiązanie może przyczynić się do wyjaśnienia okoliczności kreowania zjawisk emancypacyjnych i dochodzenia do egalitaryzmu prawnego.

Celem artykułu było pokazanie obrazu społecznych ruchów kobiet ze szczególnym uwzględnieniem ruchów motywowanych światopoglądem katolickim, ich idei i wartości, programów działania oraz kierunków planowanych przemian społecznych. Uwaga badawcza koncentrowała się na oglądzie ruchów kobiet przez pryzmat przekazu prasowego ze świadomościa, że prasa jest źródłem niepełnym, wymagajacym uzupełnienia o inne materiały dokumentacyjne, ale też jest źródłem niepewnym ze względu na cechy gatunkowe. Procedurze jej eksploracji musi towarzyszyć myśl, że wydawnictwo periodyczne ex definitione charakteryzuje się relatywnie niskim stopniem wiarygodności ze względu na tempo dostarczania informacji (niekiedy bez pogłębionego sprawdzenia danych), subiektywność (wkomponowana w perswazyjna funkcje prasy), wybiórczość tematyczna, czasem sensacyjność. Wzmiankowana niepełność wiązała się $z$ różnego rodzaju brakami czy pomyłkami w zapisie nazw własnych (nieprawidłowy zapis imion i nazwisk osób, nazw miejscowości czy instytucji). Jednak przy wszystkich niedostatkach i usterkach prasa czyni zadość wymogom stawianym w procedurze eksploracji badawczej, dostarczając unikatowej wiedzy o życiu społecznym danej populacji w określonym miejscu i czasie. Ulotność jej wartości informacyjnej (nic tak szybko się nie dezaktualizuje jak news) jest rekompensowana faktografia, której dostarcza w odpowiednim rozmiarze, przekazując wiadomości o wydarzeniach społecznych i ich uczestnikach. Ponadto - dzięki stosunkowo czytelnemu profilowi konkretnego periodyku - badacz pozyskuje dane o technikach perswazyjnych stosowanych w publicystyce.

W tytule artykułu użyte zostało pojęcie „ruchy kobiet” do określenia zjawiska „mobilizacji kobiet wokół projektu zmiany ich 
pozycji w społeczeństwie"2 . Jednak w treści artykułu zamiennie stosowano termin „ruchy kobiece”, mimo świadomości niepełnej ekwiwalencji obydwu pojęć. Korzystano $z$ frazeologii używanej w prasie dla katoliczek. Na jej łamach stosunkowo klarownie dokonywała się prezentacja płci, która znajdowała odzwierciedlenie w nazewnictwie stowarzyszen i w ich statutach czy programach organizacyjnych: kobieta (czasem to była niewiasta), pani, gospodyni domowa, pani domu, pani miłosierdzia. Funkcjonowały też feminatywne formacje słowotwórcze takie, jak: Polka, katoliczka, druhna, koleżanka ${ }^{3}$. Było też nazewnictwo odpowiednie dla funkcji organizacyjnej: prezeska, przewodnicząca, kierowniczka, liderka, które bez zastrzeżeń stosowano podczas opisów życia organizacyjnego kobiet.

W okresie międzywojennym objawiła się dażność do archiwizowania działalności kobiet. $Z$ inicjatywy aktywistek gromadzono materiały dotyczace działaczek ruchu socjalistyczno-niepodległościowego przed 1918 r. Miały stać się zaczattkiem opracowań naukowych bogatych we wspomnienia faktograficzne uczestniczek walki o niepodległość. Służyły upamiętnieniu działań na rzecz wolności politycznej państwa i jego mieszkańców. W większości miały wymiar lewicowo-liberalny o propiłsudczykowskim charakterze, zwłaszcza że części prac patronowała Aleksandra Piłsudska4. Inaczej było $z$ utrwalaniem pamięci o działaniach kobiet w środowisku

\footnotetext{
2 „Ruch kobiet”, w: Gordon Marshall (red.), Stownik socjologii i nauk społecznych, (Warszawa: Wydawnictwo Naukowe PWN, 2005), 287.

3 Ewa Młynarczyk, „Tendencje nazwotwórcze w chrematonimii społecznościowej II Rzeczypospolitej (na przykładzie nazw stowarzyszeń)”, Onomastica 2019, 219.

4 Dążność do utrwalania dziejów ruchów kobiet uwidoczniła się jeszcze przed odzyskaniem niepodległości, zob.: Zofia Daszyńska-Golińska, Przed jutrem. Współczesny ruch kobiecy wobec kwestii robotnic. Odczyt, (Kraków: Wydawnictwo „Krytyki”, 1897); Teodora Męczkowska, Ruch kobiecy. Ideały etyczno-społeczne ruchu kobiecego, (Warszawa: Ksiegarnia Gebethnera i Wolffa, 1907); Cecylia Walewska, Ruch kobiecy w Polsce. Część 1 i 2, (Warszawa: Księgarnia Gebethnera i Wolffa, 1909). Działaczki ruchów lewicowo-liberalnych i liberalnych zwracały uwagę na znaczenie masowości procesów społecznych. Taki sposób definiowania ruchu społecznego przedstawiła Wanda Pełczyńska, mająca doświadczenie w redagowaniu czasopism dla kobiet takich jak „Bluszcz” czy „Kobieta Współczesna”; zob. Jolanta Chwastyk-Kowalczyk, „Agitacja obywatelska przed- i powyborcza 1928 roku na łamach "Kobiety Współczesnej"”, Czasopismo Naukowe Instytutu Studiów Kobiecych, nr 1, 2019, 105137. W przemówieniu sejmowym Pełczyńska zwróciła uwagę, że „na całym świecie, a więc i w Polsce, coraz bardziej decydującą rolę zaczyna odgrywać zagadnienie organizowania wielkich ruchów masowych. Czyż można sobie wyobrazić, że osiagnięcie celów, wyrastających poza ramy bieżącego dnia, da się osiagnnąć przy całkowitej bierności mas, wbrew ich woli lub choćby tylko wbrew ich nastrojom”, zob. „Przemówienie Wandy Pełczyńskiej”, w: Sprawozdanie stenograficzne z 66 posiedzenia w dniu 10 lutego 1938 r. Sejm Rzeczypospolitej Polskiej, kadencja IV, sesja zwyczajna, (Warszawa: Wyd. Sejmu Rzeczypospolitej Polskiej, 1938),
} 
katolicko-narodowym, katolickim, chrześcijańsko-demokratycznym czy katolicko-konserwatywnym. Stosunkowo niewiele podejmowano inicjatyw służących utrwalaniu historii ruchów kobiecych. Celem informowania o przebiegu pracy stowarzyszeń kobiecych pod ich szyldem drukowano książki i broszury autorstwa działaczek. Wśród nich znalazły się: Helena Sołtanówna, autorka stustronicowej książki Poczatki katolickiego ruchu kobiecego $w$ Polsce, a także Kazimiera Berkanówna, Maria Findeisen, Zofia Rzepecka, Zofia Włodkowa, publikujące wykłady, pogadanki, refleksje na temat uczestnictwa w pracach krajowych i międzynarodowych zrzeszeń katoliczek ${ }^{5}$. Ukazywało się czasopismo o nazwie „Ruch Kobiecy”, wydawane przez Helenę Paygert, członkinię Stronnictwa Narodowego i aktywistkę Narodowej Organizacji Kobiet. Dwutygodnik ukazywał się we Lwowie w latach 1932-1934. Zadania relacjonowania bieżących działań realizowały organy prasowe stowarzyszeń.

Poniższy tekst został podzielony na dwie części z zastosowaniem kryterium rzeczowego. Zaprezentowano w nich wybrane elementy wiedzy o prasie dla katoliczek w Polsce międzywojennej oraz o uobecnionych w niej obrazach ruchu kobiet w porządku instytucjonalnym oraz personalnym. Lącznie ujęty obraz ruchów kobiet służył pogłębieniu wiedzy o zaangażowaniu obywatelek Rzeczypospolitej Polskiej w życie narodu i państwa. Prasa dla katoliczek podlegała regułom klasyfikowania czasopiśmiennictwa na ziemiach polskich $\mathrm{w}$ warunkach postępów procesu umasowienia wydawnictw periodycznych i definiowano ja ogólnie jako „wydawnictwa, które za zgoda władz kościelnych drukowane sa periodycznie i rozpowszechniane publicznie" ${ }^{6}$. Kobiece stowarzyszenia spo-

1. 66 [online] [dostęp: 2.09.2021]. Dostępne w World Wide Web: http://dlibra.umcs.lublin. $\mathrm{pl} /$ dlibra $/$ docmetadata?id=18179\&from=publication.

5 Helena Sołtanówna, Poczatki katolickiego ruchu kobiecego w Polsce, (Poznań: Ostoja, 1930); Kazimiera Berkanówna, Co robić? Wezwanie do pracy społecznej. Zapiski z własnych doświadczeń, (Poznań: Księgarnia św. Wojciecha, 1933); eadem, O co chodzi? Kobieta w dobie kryzysu, (Poznań: Księgarnia św. Wojciecha, 1934); Maria Findeisen, Kobieta katoliczka w świecie współczesnym według „Dni Studiów” Międzynarodowej Unii Katolickich Organizacji Kobiecych $w$ Brukseli $w$ dniach 2-6 kwietnia 1937 r. Referat wygłoszony na Zjeździe Zwiazkowym Katolickiego Zwiazku w Poznaniu, dn. 30 VI 1937, (Poznań: Katolicki Związek Kobiet, 1937); Zofia Rzepecka, Akcja Katolicka w organizacjach kobiecych, (Poznań: Katolicki Zwiazek Kobiet, 1935); eadem, W służbie dobra i prawdy. Wykłady, przemówienia, listy, (Poznań: Zjednoczenie Młodzieży Polskiej, 1931); eadem, „Wielkie zjazdy”, Zjednoczenie, nr 9 , 1938, 145, 148.

6 Adam Lepa, „Wstęp”, w: Adam Lepa (oprac.), Katalog prasy katolickiej w Polsce. Stan z 31 stycznia 1994 r., (Łódź: Archidiecezjalne Wydawnictwa Łódzkie, 1994), 3-4; Czesław 
łeczne wśród wielu różnych zadań spełniały również funkcję prasotwórcza. W miarę możliwości wydawały własne organy prasowe, choć o różnym zasięgu terytorialnym i rozmaitej frekwencyjności. Stanowiły źródło wiedzy o ruchach społecznych kobiet, ich działalności strukturalnej i programowej, wreszcie o działaczkach, które prowadziły pracę na rzecz interesów narodu i religii. Spośród nich na uwage zasługiwały czasopisma o długim trwaniu, jak „Gazeta dla Kobiet”, wydawana w Poznaniu w latach 1908-1938 i dopełniona w 1939 r. „Gazeta Kobiet”. Organ Zwiazku Stowarzyszeń Kobiet Pracujacych, potem Katolickiego Stowarzyszenia Kobiet archidiecezji gnieźnieńskiej i poznańskiej, następnie od 1936 r. Katolickiego Związku Kobiet (KZK), czyli centrali kobiecej Akcji Katolickiej, w winiecie miał zapis „Szczęść Boże!”. Na czele zespołu redaktorskiego w kolejnych latach m.in. byli: ksiądz Ignacy Czechowski, Bożena Kaczmarkówna, Halina Kokocińska, Bożena Stelmachowska, Zofia Sicińska. W Poznaniu w latach 1933-1939 ukazywał się miesięcznik „Zjednoczenie” ( $z$ zapisem nagłówkowym: Katolicki Związek Kobiet „Za Chrystusa i Ojczyznę”), organ Zjednoczenia Katolickich Związków Polek. Redagowały go Helena Sołtanówna i Helena Erzepki. W Tarnowie Katolickie Stowarzyszenie Kobiet (KSK) w latach 1936-1939 wydawało pismo „Własnymi Siłami”, z zespołem redakcyjnym w składzie Maria Dmochowska i Laura Markowska. Również w Tarnowie w 1939 r. wyszło kilka numerów periodyku „Materiał Pomocniczy na Zebranie Kółka Matek”, w postaci czterostronicowego wydawnictwa zeszytowego, nakładem Katolickiego Stowarzyszenia Kobiet. Pod firma krakowskiego Stowarzyszenia Katolickich Kobiet i Dziewcząt Pracujaccych ukazywał się miesięcznik „Kobieta Polska”. Dwumiejscowa lokalizację miało wydawnictwo Stowarzyszenia Katolickich Służących pod tytułem „Pracownica Polska”. Pismo ukazywało się w Lublinie, potem w Warszawie. Od 1924 r. miało w podtytule informację, że było tygodnikiem Polskiego Związku Zawodowego Chrześcijańskiej Służby Domowej. Realizacja zadań statutowych Katolickiego Stowarzyszenia Młodzieży Żeńskiej (KSMŻ) odbywała się za pośrednictwem miesięcz-

Lechicki, „Prasa katolicka Drugiej Rzeczypospolitej”, Kwartalnik Historii Prasy Polskiej, nr 2, 1984, 45-46.

7 Zofia Rzepecka, „Od Wydawnictwa”, Gazeta dla Kobiet, nr 1, 1936, 1. Część nakładu przez pewien czas ukazywała się jako bezpłatny dodatek do pisma „Postęp”, zob. Iwonna Michalska, „Rodzinne obowiazki kobiety w świetle katolickiego periodyku "Gazeta dla Kobiet" z lat 1918-1938", Lubelski Rocznik Pedagogiczny, nr 1, 2020, 27-41. 
nika „Młoda Polka”, redagowanego m.in. przez Czesławę Wolniewiczównę i Felicję Żurowską. Hasło pisma „Sprawie służ!” dotyczyło szerzenia wartości katolickich oraz rozwijania etyki i moralności opartej na Dekalogu. Redaktorki periodyku zmierzały do ukazania różnorodnych składników życia społecznego, starały się o to, by czytelniczki pozyskały podstawowa wiedzę na tematy ekonomiczne, filozoficzne, historyczne, polityczne. Widoczna też była dbałość o to, by pismo spełniało zadania formacyjne.

Pozycjonowanie rynku prasowego sprawiło, że ukształtowała się grupa periodyków dla dziewcząt i młodych kobiet, jak „Głos Dziewcząt Polskich”, wydawany w Krakowie przez Stowarzyszenie Sług św. Zyty, pierwsza edycja zakończyła się w 1922 r., druga miała miejsce w latach 1929-1934. Odrębny segment tworzyły czasopisma przeznaczone dla uczennic i absolwentek szkół katolickich. Względną trwałościa cieszył się organ prasowy Stowarzyszenia Chrześcijańsko-Społecznego pod opieka Matki Boskiej Dobrej Rady pod nazwa „Pisemko Kuźniczanek”, następnie „Kuźniczanka"8. Krag odbiorczy obejmował głównie środowisko Szkoły Domowej Pracy Kobiet (SDPK) w Zakopanem. W segmencie periodyków sodalicyjnych znajdował się zakopiański miesięcznik „Pod Znakiem Maryi”, organ Związku Sodalicji Mariańskich w Polsce. Pogłębianiu kultu maryjnego służyły pisma: „Cześć Maryi”, miesięcznik Związku Sodalicji Żeńskich Szkół Średnich w Polsce, Tarnów, 1923-1939, a także miesięcznik „Dzwonek Maryi”, którego nakładca była Sodalicja Mariańska, Bytom, 1921-1939. Istotna rolę odgrywały dodatki prasowe o cechach autonomicznych (własny system numerowania, odrębna paginacja). Kierownictwo Związku Kobiet Katolickich wydawało dodatek „Doniesienia Zwiazkowe Zwiazku Kobiet Katolickich”, popularnością cieszył się periodyk „Niewiasta Katolicka”, dodatek miesięczny do pisma „Nasz Kraj”, mającego w podtytule informację: „organ Zwiazku Śląskich Katolików w Republice Czechosłowackiej, poświęcony sprawom politycznym, gospodarczym, religijnym i nauce. Wychodzi w każdy piątek". Celom informacyjnym służyły okólniki, jak „Przewodnik Młodzieży Żeńskiej”, miesięcznik KSMŻ Archidiecezji Krakowskiej, ukazywał się w latach 1927-1939, redagował go ksiądz Mateusz Zdebski, a od 1935 r. Anna Orłowska.

\footnotetext{
8 Ewa Maj, „Wzorzec kobiety w prasie dla katoliczek w Polsce międzywojennej: przypadek periodyku "Kuźniczanka" (1931-1936)", Czasopismo Naukowe Instytutu Studiów Kobiecych, nr 1, 2020, 113-139.
} 
Prasa dla katoliczek była kierowana do „kobiet wszystkich stanów”. W jej treści uwypuklała się idea solidaryzmu społecznego, podbudowanego ideologia narodowa, narodowo-katolicka czy narodowo-konserwatywną. Uczestniczyła w publicznej debacie na tematy uznane za szczególnie ważne dla kobiet. Publicystki, które na ogół były czynnymi uczestniczkami ruchów katoliczek, zajmowały się zagadnieniami międzynarodowego bezpieczeństwa i pokoju, a w sprawach wewnętrznych opisywały wydarzenia ze świata polityki, ekonomiki, szkolnictwa, rynku pracy. Przedmiotem zainteresowania czyniły zagadnienia życia społecznego, takie jak: analfabetyzm, bezrobocie, ubóstwo materialne i moralne, zaniedbania $\mathrm{w}$ dziedzinie opieki medycznej. Różne kwestie codziennego bytowania jednostki ludzkiej przedstawiano pod katem obecności w nim czynnika religijnego. Filtr wyznaniowy towarzyszył tekstom poświęconym problemowi spadku liczby urodzeń, wzrastającej fali rozwodów, istnienia związków niesakramentalnych. Pojawiały się wzmianki o parach nieheteronormatywnych, a także echa dyskusji o aborcji. W sposób kategoryczny formułowano opinię w sprawie zagrożeń dla młodego pokolenia w sferze etycznej, moralnej, obyczajowej. Podkreślano znaczenie społecznych ruchów katoliczek, które powinny być przygotowane do tego, by odpowiednio wcześniej monitorować sytuację, dostrzegać niebezpieczeństwo załamania porządku społecznego, zarządzać kryzysem w warunkach demoralizacji płynącej $z$ ośrodków politycznych (komunizm, masoneria), kulturalnych (kinematografia, część wydawnictw książkowych i prasowych), obyczajowych („moda” na postępowość). Kreowany obraz był złożony z poszczególnych komponentów strategii działania, misji, celów, zadań.

\section{Obraz instytucjonalny}

Kobiety w Polsce wraz $\mathrm{z}$ uzyskaniem praw wyborczych w 1918 r. stawały się istotnym komponentem przestrzeni publicznej państwa. Plany aktywizacji środowisk kobiecych, zwalczania apatii społecznej wobec polityki zaczęły wchodzić w skład strategii ośrodków wpływu i decyzji państwa. Nie miały charakteru priorytetowego, niemniej ich pojawienie się dawało asumpt do mobilizacji sił kobiecych. W niepodległej Polsce istniały warunki do tworzenia organizacji społecznych o profilu kulturalnym, oświatowym, ekonomicznym, zrzeszających różne grupy społeczne mające konkretne 
cechy demograficzne, statusowo-warstwowe, zawodowe. Miały tradycję przedwojenna, powstawały też nowe stowarzyszenia, których liczba - według danych pochodzących z Przewodnika społecznego - w 1934 r. wyniosła 250, w tym 31 zrzeszeń kobiecych ${ }^{9}$. Na ogó1 były emanacja ruchów kobiet, a ich typologia stanowiła pochodna różnic ze względu na: (1) system wartości, zwiazek z ideologia polityczną i światopoglądem, (2) problematykę dominującą w myśli programowej, (3) środki ekspresji i styl działalności społecznej.

Zajmowanie przestrzeni publicznej, a przynajmniej jej fragmentu, wymagało solidarności w obrębie płci. Jednak istniejące kobiece organizacje społeczne reprezentowały odmienne idee i wartości, miały przeciwstawne interesy, artykułowały rozmaite programy. Kobiety nie wytworzyły sytuacji, w której mogły stać się jednolitym, zbiorowym podmiotem politycznym. Podziały światopoglądowe utrzymywały stan dyferencjacji kobiecych stowarzyszeń społecznych przez całe dwudziestolecie międzywojenne, co skutkowało bogactwem rynku periodyków adresowanych do czytelniczek. W prasie dla katoliczek w sposób oczywisty uwaga wydawców, redaktorów i publicystów była skupiona na ruchu społecznym, który reprezentował wartości religijne. Stąd jedynie incydentalnie i na zasadzie kontrastowania środowisk kobiecych odnoszono się do form organizacyjnych powstałych wokół idei odległych od katolicyzmu, szczególnie dezaprobowano działalność komunistek i socjalistek. $\mathrm{Na}$ temat katolickich stowarzyszeń kobiecych formułowana była niemal jednobrzmiąca opinia, zgodnie $z$ która „Śmiało można powiedzieć, że KSK jest prawdziwa szkoła życia, w której każda kobieta może nauczyć się żyć po katolicku, a także nauczyć się po katolicku wychowywać swoje dzieci”, a użycie skrótowca bez wyjaśnienia, że chodziło o Katolickie Stowarzyszenie Kobiet, świadczyło o zaufaniu do czytelniczek i ich wiedzy na temat instytucjonalizacji ruchu katoliczek ${ }^{10}$.

W odniesieniu do ruchów katoliczek skala idei i wartości politycznych mieściła się $\mathrm{w}$ przestrzeni wyznaczonej nurtami myśli narodowodemokratycznej, narodowo-katolickiej, katolickiej, chrze-

\footnotetext{
9 Antoni Pruszkowski, „Przewodnik społeczny. Dane monograficzno-orientacyjne 250-ciu polskich stowarzyszeń i związków: I. Młodzieży, II. B.[yłych] wojskowych, III. Ogólnospołecznych, IV. Kulturalno-oświatowych, V. Gospodarczych, VI. Kobiecych, VII. Akcji Katolickiej, VIII. Zw.[iązków] zawodowych, IX. Różnych", (Warszawa: Drukarnia P. Brzeziński, 1934), 7-10nn.

10 „KSK w życiu kobiety”, Własnymi Siłami, nr 7, 1938, 2.
} 
ścijańsko-demokratycznej, narodowo-konserwatywnej $z$ uwzględnieniem pojęcia „tradycja” oraz z gotowością do eksponowania cech myślenia elitarystycznego w relacjach klasowo-warstwowych, ale też ekskluzywno-narodowego oraz ekskluzywno-katolickiego, tonowanego przykazaniem miłości bliźniego. Na łamach prasy domagano się od kobiet, by podjęły się czynnej pracy społecznej w duchu troski o stan moralny ogółu Polaków i w obliczu niebezpieczeństwa deprawacji młodego pokolenia. Pojawiły się artykuły analityczne i interwencyjne spowodowane oceną postępów immoralizmu, niszczenia ładu społecznego, relatywizowania norm obyczajowych. Jednak nadmieniano, jak w wypadku "Gazety dla Kobiet” w 1918 r., że „pobożność jest podstawa pracy społecznej”"1. Siedem lat później Bożena Stelmachowska w tekście Nowy ruch wyjaśniała, że

zjawiskiem dodatnim $\mathrm{w}$ tym ruchu nowym jest i to jeszcze, że powołując do życia towarzystwa kobiece stawia się je od razu na szerszej platformie, zakreśla im się dalsze horyzonty, wyznacza wznioślejsze cele. Dalej jeszcze powiedzieć można, że wzniosłość celów łączy się z pewnego rodzaju praktycznością mająca na oku zdrową korzyść dla jednostki ${ }^{12}$.

Ze względu na wspomnianą różnorodność ideową poszczególnych ruchów kobiet na ziemiach polskich czytelniczkom należało wytłumaczyć odmienności światopoglądowe i programowe między emancypacyjnymi ośrodkami socjalistycznymi i liberalnymi a środowiskiem katolickim czy katolicko-narodowym wraz z derywatami. Bożena Stelmachowska eksponowała konkretne zadania katoliczek w stosunku do wartości narodu i państwa polskiego, w wykonywaniu obowiązków widząc źródło pozytywnej siły uczestniczek ruchu. Podobnie postępowały inne publicystki, ale część $z$ nich ponadto podjęła się delimitacji ruchów katolickich oraz ruchów niekatolickich, wykorzystując pojęcia emancypacji i feminizmu, przy czym nie zawsze się od nich odżegnywano mimo negatywnej konotacji wśród duchownych i części środowiska kobiecego ${ }^{13}$. Odbiorczynie prasy dowiadywały się, że

11 „Pobożność podstawa pracy społecznej”, Gazeta dla Kobiet, nr 18, 1918, 69-70.

12 B. St. [Bożena Stelmachowska], „Nowy ruch”, Gazeta dla Kobiet, nr 2, 1925, 1.

13 Duchowieństwo katolickie na temat ruchów emancypacyjnych kobiet wypowiadało się negatywnie, widzac w nich „niefortunne wprowadzenie logiki sztucznej i bezpodstawnej, a poniewieranie wiekuistymi prawami logiki rodu ludzkiego powszechnej i bezwzględnej”, A.L. [Augustyn Lipnicki], Tak zwana „emancypacja” a chrześcijańskie stanowisko niewiasty. 
emancypacja, słowo łacińskie, oznacza uwolnienie niewolnika, w przenośnym znaczeniu wyzbycie się czegoś lub wyzwolenie się spod czegoś. Wyzwolenie się kobiety „spod jarzma niewolniczego mężczyzny", nadanie jej praw do kształcenia się, do zarobkowania, udziału w życiu obywatelskim obok mężczyzny i na równi $z$ mężczyzna, oto dążenie, $z$ którym spotykamy się po dziś dzień na każdym kroku, dążenie, które stanowi prawie całą treść ruchu kobiecego $^{14}$.

Aprobatywna postawa odnośnie do terminologii emancypacyjnej miała swoje przeciwieństwo w postaci dezaprobaty wpływów „emancypantek postępowych”, w których działalności upatrywano źródło deprawacji kobiet, zachęcania do zgubnej walki płci, zapominania o „naturalnych i przyrodzonych” obowiazkach wobec rodziny. Przekonywano, że lewicowy i liberalny ruch emancypacyjny miał charakter antychrześcijański, socjalistyczny, masoński. Należało go zwalczać ze względu na przyjmowany $z$ góry obraz działań rozkładowych w stosunku do wartości narodowych i religijnych. Obok wielu odrębności ideowych i światopoglądowych między katolickim a niekatolickim ruchem kobiecym zwracano uwage na to, że katoliczki zabiegały nie tylko o gwarancję swoich praw, ale też rozumiały znaczenie obowiązków, które miały względem spraw prywatnych (domowych, rodzinnych) oraz publicznych (narodowych, obywatelskich) $z$ uwzględnieniem interesów wierzenia religijnego. Różnica była eksponowana ze względu na cechy kobiet, wnoszacych do życia społecznego pierwiastki ładu, spokoju, koncyliacyjności. Widziano w nich strażniczki nienaruszalnych zasad czystości moralnej, tradycyjnej obyczajności, bezinteresownej ofiarności i poświęcenia.

W świetle publicystycznego przekazu prasowego ruch społeczny katoliczek kierował się własnymi zasadami, odkrytymi czy wykreowanymi w trakcie formowania się środowiska „narodowych

W dwóch częściach: krytycznej i sprawozdawczej, t. 1, Część krytyczna, (Warszawa: Księgarnia Wojciecha Cithurusa, 1887), 17.

14 "O równe prawa dla kobiet”, Gazeta dla Kobiet, nr 23, 1918, 89. „Z tym łączy się oczywiście pewien nieznany przedtem u kobiet, polskich... feminizm. Jest to zjawisko zupełnie słuszne, jeżeli się zważy, że związki kobiece powołane sa przede wszystkim do popierania interesów kobiecych, do wnikania w dolę i niedolę kobiety pracującej, w jej prawa i bezprawia, nierówność wynagradzania, brak ochrony, czy też niezastosowanie przepisów ochronnych w kwestię matki pracującej zawodowo i związanego z tym wychowania jej dziecka”, B. St., „Nowy ruch”. 
feministek", opartego na społecznym nauczaniu Kościoła katolickiego, a w świecie prasowym kierującego się zasadą: „Apostolstwo prasy katolickiej, to jeden $z$ punktów programu naszej pracy"15. W figure „feministki narodowej” wkomponowana była dążność do wykazania, że kobiety mogły być samodzielnymi, świadomymi swoich obowiązków uczestniczkami życia społecznego bez konieczności manifestacyjnego żądania egalitaryzmu płci. Do modelu „kapłanki domowego ogniska" dodawano model rozumnej obywatelki-katoliczki, która mogła wpłynać na losy narodu i państwa. Notabene manifestacja nie była potrzebna, albowiem uznano, że obecność czynnika kobiecego w przestrzeni publicznej, zaangażowanie w sprawy społeczne, wzrastajacy udział w rynku pracy, oznaczały „naturalny” wyłom w tradycjonalistycznej formule płci. Odstępstwo od utrwalonego modelu stosunków społecznych dokonywało się nawet wówczas, gdy panie deklarowały, że pracy zarobkowej powinny oddawać się wyłącznie osoby niezamężne, obsadzające się w rolach zawodowych akceptowanych w systemie patriarchalnym, jak nauczycielka w szkole dla dziewczat czy opiekunka w ochronce, ewentualnie pracownica biurowa ${ }^{16}$. Był też jeszcze jeden powód zainteresowania aktywnością zarobkowa kobiet, gdy skonstatowano, że niezależnie od społecznego statusu pani domu czy gospodyni domowej miały wpływ na zachowania konsumenckie, oddziałujacc na decyzje zakupowe rodziny. Zwrócono uwage na rolę czynnika kobiecego przy realizacji hasła unarodowienia handlu i polonizacji rynku usług celem eliminowania „żywiołów obcych”, głównie żydowskich i niemieckich. Różnice między „feministkami radykalnymi” i „feministkami narodowymi" ustalano w porzadku opozycyjnym $z$ zastosowaniem kategorii: kosmopolityzm - patriotyzm, relatywizm moralny - spójność

\footnotetext{
15 Janina Kaźmierska, „30 lat”, Gazeta dla Kobiet, nr 4, 1936, 39; zob. Ewa Maj, „"Feminizm narodowy", czyli o kobietach w Narodowej Demokracji”, w: Maria Marczewska-Rytko, Dorota Maj, Marcin Pomarański (red.), Feminizm, (Lublin: Wydawnictwo Uniwersytetu Marii Curie-Skłodowskiej, 2015), 217-229.

16 „Praca matek poza domem”, Niewiasta Katolicka, nr 12, 1932, 1. W stosunku do kobiet mających własną rodzinę zwracano uwagę na przeciążenie „potrójnym zadaniem: pracownicy, gospodyni i matki”, „Zagadnienie pracy kobiet na Międzynarodowej Konferencji Pracy”, Gazeta dla Kobiet, nr 9, 1930, 82. Z zainteresowaniem, choć o niejednolitym charakterze i natężeniu, prasa dla katoliczek opiniowała tzw. ustawę celibatowa, która zmuszała zamężne nauczycielki do odejścia od zawodu, zob. Maria Bauchrowicz-Tocka, „Zakonspirowane mężatki", czyli o ograniczeniach obyczajowych i prawnych wobec pracujących kobiet na łamach "Tygodnika Kobiety"”, w: Małgorzata Dajnowicz, Adam Miodowski (red.), Polityka i politycy w prasie XX i XXI wieku. Polityka w prasie kobiecej, (Białystok: Wydawnictwo Uniwersytetu w Białymstoku, 2019), 103-116.
} 
moralna, swawola - rozumnie interpretowana wolność, egzaltacja i nadużycie - spokój i rozwaga, żądanie praw - realizowanie obowiązków.

Wspomniane zmiany w sektorze społeczno-ekonomicznym, rosnąca pozycja kobiet w niestereotypowych profesjach (lotniczka, docentka, posłanka, radna) sprawiły, że ruch katoliczek wzmógł uwage skierowana na sytuację pracownic najemnych, podnosząc kwestię ich dyskryminowania w miejscu pracy, braku szansy na karierę przy wzrastającym ryzyku zwolnienia. Dlatego mocno zaakcentowany był profil zawodowy (zwiazkowy) ruchów katoliczek ${ }^{17}$. W „Gazecie dla Kobiet” Bożena Stelmachowska następująco uzasadniała konieczność podjęcia kwestii nierówności zawodowej ze względu na płeć:

Ktoś niewtajemniczony $\mathrm{w}$ te sprawy nie ma pojęcia, jak trudno zdobyć kobiecie stanowiska wyższe, z pełną odpowiedzialnościa! Konstytucja polska nie przewiduje co prawda żadnych ograniczeń w przyjmowaniu kobiet na stanowiska wyższe czy choćby najwyższe. Lecz moc dawnych przyzwyczajeń, zaśniedziałych antyfeministycznych uprzedzeń jest tak wielka, że w praktyce kobieta uchodzi zawsze za coś gorszego i nie umiejącego ponosić odpowiedzialności za swoje czyny. Kobieta starsza, inteligentna jakże często ustępuje miejsca młokosowi, stawiającemu zaledwie pierwsze kroki w urzędzie i nie rokujacemu bynajmniej wielkich nadziei! Świat jednak uważa, że tak wszystko jest w porządku! ${ }^{18}$.

Tego typu deklaracja wymagała neutralizacji, dlatego obok niej znalazło się wyjaśnienie dotyczące mechanizmów tworzenia i funkcjonowania katolickich kobiecych ruchów społecznych, mających szczególne zadania:

Wytworzyła się więc sytuacja taka, że obok towarzystw o charakterze ideowo-gospodarczym, opartych na zasadach narodowo-ka-

\footnotetext{
17 Wyjaśniano: „Kobieta stanęła obok mężczyzny w fabryce: przy warsztacie, w biurze, tym samym zrównała się co do praw z mężczyzna i weszła w życie publiczne. Dzisiaj kobiety mają swoje własne organizacje, gazety, zwołuja zebrania, przemawiaja, urządzają zjazdy”, „Udział kobiet w życiu politycznym”, Kobieta Polska, nr 12, 1918, 1. „Hasło zrzeszania kobiet pracujących według stałego programu organizacyjnego przejawiało się u nas od lat kilkunastu, a jako owoc usiłowań i pracy w tym kierunku były organizacje luźne, tworzące się najpierw przy większych centrach fabrycznych”, „Sprawozdanie Głównego Wydziału Związku Katolickich Stowarzyszeń Dziewcząt i Kobiet Pracujących z działalności za rok 1916”, Kobieta Polska, nr 6, 1917, 1.

18 B. St., „Nowy ruch”.
} 
tolickich, poczyna się już obecnie ruch kobiecy, ściśle zawodowy. Jest on tym potrzebniejszy, że w niektórych kategoriach stanowisk urzędniczych popiera się wyraźnie mężczyzn niejednokrotnie posiadających gorsze kwalifikacje i mniej zdolności od rugowanych bezwzględnie kobiet ${ }^{19}$.

Prasa, wskazując na zawodowy charakter części ruchów katoliczek, tłumaczyła, że zwiększał możliwości pozyskiwania wpływu na zachowania i postawy Polek. Miał odebrać bądź osłabić niektóre argumenty stosowane przez „emancypantki postępowe”, ogłaszające programy egalitaryzmu ekonomicznego kobiet. Dlatego organizowane były różne formy pomocy dla pracownic przy planowaniu zajęć zarobkowych w ten sposób, by zabezpieczyć dobro rodziny. Zachęcano do budowania więzi koleżeńskich $z$ innymi pracownicami, do podnoszenia kwalifikacji zawodowych, ponadto przyuczano do higienicznego trybu życia ${ }^{20}$. Dopełnieniem oddziaływania na kobiety stała się praca działaczek Akcji Katolickiej na rzecz odrodzenia duchowości, pobudzenia zaangażowania religijnego osób świeckich, umacniania świadomości społecznych zadań katoliczek. W czasopiśmie „Zjednoczenie” przypominano jedno z haseł ruchu „Katolickie zasady społeczne podstawa socjalnej przebudowy świata”, majace wymiar normujacy status pracownic. Ekspertka udzielała porad w zakresie umów o pracę, omawiała ich rodzaje, przedstawiajac skutki prawne umów zbiorowych i indywidualnych ${ }^{21}$.

Życie organizacyjne katoliczek podlegało ogólnym normom działalności stowarzyszeń społecznych. Wytworzenie rytuałów i symboli o klarownej identyfikacji świadczyło o dojrzałości ruchu, o postępach jego instytucjonalizacji, a dla prasy było okazją do oddziaływania na wyobraźnię czytelniczek, z czego chętnie korzystano, gdy

\footnotetext{
19 Ibidem.

20 Część porad dotyczyła ochrony dłoni pracownic przed zniszczeniem skóry, przed zaniedbaniem czystości rąk i ich ogólnej estetyki. Nadmieniano, że „nic kobiecie tak nie odbiera uroku jak zaniedbanie tego obowiazku”, dlatego podawano szczegółowe wskazówki na temat sposobów pielęgnacji z wykorzystaniem mydła, oliwy, lanoliny czy gliceryny, Juliuszowa Albinowska, „Rady higieniczne dla kobiety pracujaccej”, Gazeta dla Kobiet, nr 1, 1925, 8.

21 L. W-K., „Nasze hasło: "Katolickie zasady społeczne podstawa socjalnej przebudowy świata"”, Zjednoczenie, nr 3, 1938, 34. W 1938 r. redakcja pisma informowała o powołaniu specjalnej komisji do spraw pracy zawodowej kobiet przy KZK, ponadto ogłosiła ankietę zawierająca pytania o system ubezpieczeń społecznych, o sytuację socjalna pracownic i kompetencje zawodowe oraz o stopień satysfakcji z wykonywanych obowiązków. Był to nieczęsty przypadek, gdy w prasie dla katoliczek podjęto problem aspiracji zawodowych kobiet, „Kobieta w pracy zawodowej. Nasza ankieta", Zjednoczenie, nr 4, 1938, 49-51.
} 
w wielu różnych tekstach poświęconych sprawom stowarzyszeń pojawiały się opisy obrzędowości organizacyjnej. Członkinie uczestniczyły w ceremoniałach wewnątrzorganizacyjnych, jak poświęcenie sztandaru stowarzyszenia, chóralne śpiewanie pieśni hymnicznych (w chwilach uroczystych uczestniczki spotkania śpiewały Boże, coś Polskę, Rotę, My chcemy Boga, młodzież żeńska na ogół intonowała pieśn Hej, do apelu!), uroczyste przyjmowanie adeptek pracy społecznej, przygotowanie zwyczajowych spotkań bożonarodzeniowych (opłatek, gwiazdka) czy wielkanocnych (święconka), urządzanie zabaw choinkowych dla dzieci'i ${ }^{22}$. Absolwentki wspomnianej wcześniej SDPK, czytelniczki „Pisemka Kuźniczanek” oraz „Kuźniczanki”, gromadziły się wokół znaku, na który składały się: krzyż, kądziel i książka, będącego graficznym emblematem Szkoły. Odwołania do symboliki chrześcijańskiej były wielokrotnie stosowane, choć w różnych wariantach, właściwych danemu stowarzyszeniu. Przykładem służyła odznaka organizacyjna KZK ustanowiona w 1936 r. Miała postać krzyża, na którego poprzecznych ramionach znajdował się napis Pro Christo, a na dolnym ramieniu Et Patria, czyli „Dla Chrystusa i Ojczyzny". Była używana jako znak formacyjny, umieszczany w dokumentacji sygnowanej przez KZK, oraz jako odznaka członkowska ${ }^{23}$. Jeśli członkini nie miała odznaki, mogła użyć barw organizacyjnych, przeplatając biało-żółtą wstążeczkę i przypinając ja do ubrania. W warstwie słownej obowiazkowa była tradycyjna formuła powitalno-dziękczynna: „Szczęść Boże”, „Bóg zapłać”.

$\mathrm{W}$ procedurze integrowania kobiet $\mathrm{w}$ ruchu katolickim korzystano $z$ powszechnie znanych schematów rytualnych zachowan, które dotyczyły urządzania odświętnych spotkań i rutynowych zebrań organizacyjnych. Miały różny charakter (religijny, świecki), ale każdorazowo starano się o nadanie im szczególnej wymowy. Gdy powstawały struktury nowego lokalnego koła katoliczek, czytelniczki otrzymywały informację o księdzu patronie, zasługach dla miejscowej ludności, ponadto dowiadywały się o kompetencjach

\footnotetext{
22 „Poświęcenie sztandaru Stowarzyszenia Kobiet Pracujacych w Rawiczu”, Gazeta dla Kobiet, nr 1, 1925, 3; Janina Strawińska, „Nasze święto organizacyjne”, Zjednoczenie, nr 2, 1937,30 .

23 „Decyzja na podstawie art. 1 ust. (I) dekretu $z$ dnia 2 października 1935”, Ogniwo, nr 11, 1936, 7. Wyjaśniano, że: „Nasza oznaka związkowa jest prosta lecz piękna; napisem "Dla Chrystusa i Ojczyzny“ oznajmiająca, że pragniemy szerzyć Królestwo Chrystusowe dla szczęścia naszego kraju”, „25 marca”, Gazeta dla Kobiet, nr 3, 1936, 27; „Zatwierdzenie naszej odznaki członkowskiej", Zjednoczenie, nr 9, 1936, 145.
} 
przewodniczącej koła oraz o zadaniach do wykonania w najbliższym czasie. Dostawały też wzmiankę o korzyściach, ,jakie daja stowarzyszenia nasze, mianowicie poznanie obowiazków religijnych i narodowych, oświatę i także wspólną rozrywkę"24. Chwilę oddechu zapewniały spotkania towarzysko-rekreacyjne, urządzano gry na świeżym powietrzu, zapraszano na zabawy taneczne. Na finał spotkania wprowadzano akcenty patriotyczne, gdy „przewodnicząca polecała zebranym czcić pamięć sławnych przodków naszych, spełniać gorliwie obowiązki narodowe i serdecznie ukochać mowę i pieśni ojczyste" 25 . W latach 30 . ubiegłego wieku świąteczny charakter miały akademie papieskie, organizowane przez Akcję Katolicka w celu oddawania hołdu Piusowi XI i upowszechniania nauczania kościelnego. Bardziej świecki charakter miały uroczystości na dzień imienin prezydenta RP Ignacego Mościckiego. Zalecano, żeby „w nabożeństwie wziąć udział ze sztandarem, a na zebranie uroczyste przygotować ... odpowiedni referat i deklamację", która była podniosła, ale bez obowiązkowych akcentów religijnych ${ }^{26}$. Podjęto też próby tworzenia obrzędowości służącej integrowaniu poza formalnymi strukturami organizacyjnymi. Wśród zaleceń dla młodych członkiń było uczestnictwo przy zaślubinach koleżanek wychodzacych za mąż. Przy wejściu do świątyni miały tworzyć szpaler, odprowadzić młoda parę do ołtarza, brać czynny udział w eucharystii, następnie po ceremonii zaślubin młodej mężatce wręczyć „przypięta na biało-żółtej rozecie $z$ wstą̇̇i oznakę KSK i prosić, by jak najprędzej przybyła na zebranie Oddziału KSK, składając przy tym młodej parze serdeczne życzenia. Moga też prosić pana młodego, by nie bronił swej żonie należeć do KSK, bo na pewno wtedy będzie dobra żona”"27. Oprócz dostarczania czytelniczkom wiedzy o świecie, redaktorki prasy dla katoliczek przyuczały je do specyficznej estetyki i wrażliwości na sprawy kultury będącej mieszanką artystycznych motywów ludowych i religijnych (kościelnych). Organy prasowe stowarzyszeń zamieszczały wskazówki w kwestii przygotowywania amatorskich przedstawień teatralnych, tematycznych

\footnotetext{
24 „Sprawy Związu i Stowarzyszeń”, Gazeta dla Kobiet, nr 18, 1918, 76.

25 Ibidem; Z.P., „Kluby kobiece”, Gazeta dla Kobiet, nr 2, 1923, 3; „Jak obchodzić Dzień Matki na wsi”, Gazeta dla Kobiet, nr 11, 1928, 112.

26 „Doniesienia Sekretariatu”, Przewodnik Młodzieży Żeńskiej, nr 1, 1938, 2; „Na dzień imienin", Gazeta dla Kobiet, nr 2, 1936, 15.

27 „Katolickie Stowarzyszenie Kobiet”, Posłaniec Diecezjalnego Instytutu Akcji Katolickiej, nr 2, 1939, 58.
} 
wieczornic („Królowa Korony Polskiej”, „Śladem Maryi”, „Rodzina ostoja”), deklamacji religijno-patriotycznych ze spiewem solowym i chóralnym. Zalecenia dotyczyły także kwestii ubioru, ponieważ „Młoda Polka zawsze ubraniem i całym układem powinna wyróżniać się od panien innych narodowości, mody ślepo nie naśladować, nie być lalką z żurnala mód, przed zwierciadłem upozowana, lecz zawsze i wszędzie być sobą, być Polka!!” ${ }^{28}$.

$Z$ prasowych rubryk poświęconych komunikatom wewnątrzorganizacyjnym (w rodzaju $Z \dot{z}$ ycia stowarzyszenia) wyłaniał się obraz prężnych struktur organizacyjnych, sprawnie i mądrze zarzadzanych oraz złożonych $z$ aktywnych, oddanych sprawie członkiń, które bezinteresownie pracowały dla dobra ogółu. Czytelniczki dowiadywały się o udziale $\mathrm{w}$ międzynarodowym ruchu kobiecym i sukcesach, jakie odnosiły członkinie krajowych stowarzyszen, jak hr. Władysławowa Zamoyska, wchodzacca w skład zarządu Międzynarodowej Unii. W 1931 r. obrady Unii odbyły się w Warszawie z udziałem przedstawicielek katolickich związków kobiet z Belgii, Francji i Holandii. Polskę reprezentowały - oprócz Zamoyskiej - Zofia Rzepecka, przewodnicząca Katolickiego Związku Polek, Teresa Sapieżyna $z$ oddziału w Krakowie oraz Halina Doria-Dernałowicz, członkini zarządu Unii Młodych ${ }^{29}$. Obraz ruchu katoliczek był spójny, zawierał wiele nawiązań do sukcesów odnoszonych w różnych sferach życia społecznego. Jednak redaktorki i publicystki prasy dla kobiet niekiedy zdobywały się na szczerość, gdy widziały niedostatek działalności formacyjnej. O słabości organizacyjnej stowarzyszeń z przekora pisała redakcja miesięcznika „Młoda Polka”, gdy ogłaszała Szukam KSMŻ, co miało przypomnieć czytelniczkom, że należało intensyfikować prace strukturalna i programowa. Metaforyczna wizytacja organizacyjna miała zmienić się $\mathrm{w}$ wizytację realna na wzór przedstawicieli władz państwowych dokonujących kontroli instytucji publicznych (autorka tekstu publicystycznego konstatowała: „Coś takiego, jak pan premier Składkowski”) ${ }^{30}$. W żartobliwej formie, ale $z$ gotowością do pokazania usterek w pracy poszczególnych oddziałów podawała przykłady fasadowego działania kierownictwa i członkiń stowarzyszenia. W wielu miejscowościach diagno-

28 P.W., „Jak to dawniej bywało. Wspomnienia babuni”, Gazeta dla Kobiet, nr 17, 1918, 67.

29 „Z obrad Międzynarodowej Unii Katolickich Związków Kobiecych w Warszawie”, Dziennik Bydgoski, nr 129, 1931, 6.

30 Druhna Redaktorka, „Szukam KSMŻ!”, Młoda Polka, nr 10, 1937, 142. 
zowała luki w pracy lokalnej organizacji: „choć na drzwiach wabi mój wzrok godło organizacyjne, choć w kościele dojrzałam sztandar za 600 zł, odchodzę smutna i mówię z żalem - a jednak nie ma, nie ma!"31. Zachęcała czytelniczki do korespondowania $z$ redakcją celem oceny sytuacji poszczególnych oddziałów KSMŻ, zastrzegając, że „nie piszcie o akademiach, nie piszcie o poświęconych sztandarach za 600 zł. Napiszcie w jaki sposób w różnych dziedzinach życia przejawia się Wasza katolicka działalność"32. W ten sposób poddała krytyce stan marazmu organizacyjnego bądź pozorowanej działalności i przypominała idee i wartości, jakie przyświecały katolickiemu zrzeszeniu.

Krytycyzm dotyczył spraw zwiąanych $z$ ochrona dziewcząt i kobiet przed demoralizacja, $z$ działalnością prewencyjna oraz wspieraniem pracy działalności Towarzystwa Katolickiej Opieki Dworcowej (misji dworcowych). Wielokrotnie w przekazach prasowych doceniana była służba społeczna mająca na celu ochronę niepiśmiennych, ubogich dziewcząt, zagrożonych utratą wolności osobistej (handel żywym towarem), podlegających deprawacji, a nadto zagrożonych popadnięciem w nierząd. Panie ze stowarzyszenia deklarowały pomoc w znalezieniu miejsca pracy oraz noclegu (przykładowo, w poznańskiej „Gościnie”) dla samotnie podróżujacych niezamożnych kobiet, pozbawionych opieki bliskich osób. Kierowano słowa zachęty do członkin katolickiego ruchu kobiecego, by zgłaszały akces do patroli nadzorujących dworce i wychwytujacych samotne, bezradne dziewczęta i młode kobiety ${ }^{33}$. W ramach pracy formacyjnej pokazywano, jak działa Stacja Opiekuńcza nad Matka i Niemowlęciem, firmowana przez poznański ośrodek Związku Kobiet Pracujaccych - zachęcano do upowszechniania informacji o jej działalności, w tym o bezpłatnym poradnictwie ${ }^{34}$. Każdy opis działań członkiń ruchu kobiecego zawierał dane o postępach pracy słu-

\footnotetext{
31 Ibidem.

32 Ibidem. Symptomatyczne były zalecenia, żeby artykuł „Szukam KSMŻ” był odczytany i przedyskutowany na zebraniu kierownictwa, a podczas kolejnego spotkania należało podzielić się przemyśleniami na temat stanu organizacyjnego w swojej parafii. Redakcja zachęcała do rozwinięcia inwencji członkiń koła, żeby oddolnie podejmowały działania na rzecz intensyfikacji pracy, „Ku pamięci”, Młoda Polka, nr 10, 1937, 156.

33 „Katolicka Opieka Dworcowa w Poznaniu”, Gazeta dla Kobiet, nr 1, 1925, 6. Prasa drukowała wykazy adresowe misji dworcowych w Polsce. Pod koniec międzywojnia w kraju działały dwadzieścia dwie misje dworcowe prowadzone przez katolickie zrzeszenia kobiece, „Wykaz Misji Dworcowych w Polsce”, Młoda Polka, nr 7, 1939, 109.

34 „Nasza Stacja Opiekuńcza nad Matką i Niemowlęciem”, Gazeta dla Kobiet, nr 2, 1925, 2.
} 
żącej ochronie przed deprawacją. Jednak tekst Czesławy Wolniewiczówny pod znamiennym tytułem Czy moge być sprzedana?, wydrukowany na łamach miesięcznika „Młoda Polka” w lipcu 1939 r., był dowodem, że wielu zagrożeń życia kobiety nie udało się wyeliminować ${ }^{35}$. Zawierał rozważania dotyczące sposobów zwabiania dziewczat i kobiet do uprawiania nierządu, do „najpodlejszej niewoli” oraz do "piekła kobiet”, identyfikowanego ze skutkami handlu żywym towarem. Tekst miał charakter informacyjno-perswazyjny, ponieważ zawierał dane statystyczne obrazujace skale problemu, ponadto mieścił w sobie wiadomości o działaniach policyjnych oraz o efektach pracy katolickich stowarzyszeń kobiecych ${ }^{36}$. Jednocześnie dowodził bezradności wobec zjawisk społecznych, które wymagały rozwiązań kompleksowych.

W przekazie prasowym nieustannie przewijał się wizerunek katoliczki czynnie uczestniczącej w życiu gospodarczym i społecznym Polski. Miała być świadoma członkinia narodu i roztropną obywatelka państwa. Powinna dysponować stosowną wiedza o świecie i mechanizmach nim rządzących, przynajmniej w wymiarze dostatecznym do tego, by rozumnie realizować obowiązki - we frazeologii „Niewiasty Katolickiej” istniał nakaz, by „w umysły panieńskie od wczesnej młodości wpajać duchowe wzory niewieścich powinności”37. Działalność praktyczna polegała na wspieraniu samorozwoju, wzmacnianiu kompetencji społecznic, umożliwieniu odpowiedzialnego udziału w życiu narodu i państwa. Poszczególne stowarzyszenia systematycznie organizowały kursy, które służyły nauczeniu się pożytecznych umiejętności. Na ogół zachęcano do udziału w kursach: oświatowym (nauka literatury ojczystej, historii, spiewu) czy prowadzenia gospodarstwa domowego, uczono reguł życia małżeńskiego (wśród prelegentów były osoby świeckie i duchowne), ponadto $\mathrm{w}$ sferze zainteresowania członkin pozostawały tak rozmaite kursy, jak nauka księgowości czy szkolenie

\footnotetext{
35 Czesława Wolniewiczówna, „Czy mogę być sprzedana?”, Młoda Polka, nr 7, 1939, 106.

36 Był opatrzony rysunkowymi informacjami obrazującymi przebieg działania przestępców zwabiających dziewczęta i kobiety do domów publicznych. Część ilustracji miała charakter poradniczo-prewencyjny, zawierała wskazówki w sprawie ostrożnego i racjonalnego postępowania samotnych kobiet przybywających do miasta w poszukiwaniu pracy zarobkowej. Jeden $z$ rysunków opatrzono podpisem: „Przyjechawszy do dużego miasta za praca, najlepiej oddać się w opiekę pani z Misji Dworcowej z biało-żółtą opaską na ręku”, Czesława Wolniewiczówna, „Czy mogę być sprzedana?”, Młoda Polka, nr 7,1939, 107.

37 „Dwojakość w powołaniu żeńskim”, Niewiasta Katolicka, nr 1, 1932, 2.
} 
w zakresie przygotowywania ozdób choinkowych. Adresowano je do kobiet $\mathrm{z}$ różnych grup społecznych, zarówno do pań bardziej zamożnych, jak i do żeńskiej służby domowej celem podniesienia jej kwalifikacji ${ }^{38}$. Opłaty przez nie wnoszone obejmowały wyłącznie rzeczowa stronę nauczania, natomiast stowarzyszenie fundowało lokal w Domu Zwiazkowym, a także opał i energię elektryczną. O stopniu zaangażowania $\mathrm{w}$ upowszechnianie tej formy aktywności świadczyły inwestycje $\mathrm{w}$ budowę pomieszczeń przeznaczonych do specjalistycznych zajęć i wyposażonych w niezbędne pomoce naukowe. Spektakularnie organizowane były wystawy robót ręcznych, prezentowano efekty szycia bielizny kościelnej, przedmiotem dumy były prace poświęcone życiu i działalności świętych patronów kół związkowych. $Z$ opisów prasowych tchnął optymizm wynikający $z$ postępów nauczania, $z$ umiejętności organizowania zajęć, zapraszania specjalistów i specjalistek, budowania więzi grupowej. Nawet drobne wzmianki o finalizacji konkretnego kursu dopełnione były informacja, że „kurs zakończyła wspólna "kawka", na której wesołość i serdeczność zlewały się w ujmująca całość, wywołując w kursistkach wdzięczność dla ks. Patrona za urządzenie kursu oświatowego" 39 .

Szczególnego rodzaju kursy edukacyjne dotyczyły doskonalenia umiejętności kierowniczych. Były przeznaczone dla członkiń zarządów organizacyjnych, gdy uruchamiano szkolenie wzbogacające ich techniki pracy formacyjnej. W programie wykładów

\footnotetext{
38 Propagowano kursy gotowania, thumacząc, że „znajomość dobrej i praktycznej kuchni przyda się każdej służącej domowej, która często jest zmuszona całe życie poświęcić temu zawodowi”, „Pierwszy kurs kucharstwa”, Gazeta dla Kobiet, nr 2, 1925, 2. W prasie dla kobiet przy kreowaniu obrazu katolickiego ruchu społecznego objawiał się typ aktywności kobiecej w sferze kształcenia i samokształcenia. Swego rodzaju „imperatyw edukacyjny” nieustająco towarzyszył wszelkim wzmiankom o członkiniach stowarzyszeń katolickich, o ich pracy na rzecz wzbogacania własnej umysłowości i propagowania oświaty wśród innych osób. Dla wzmocnienia siły przekazu przywoływano fragment encykliki $O$ sytuacji religijnej papieża Piusa XI, skierowanej do episkopatu Meksyku w marcu 1931 r.: „do praktyk religii chrześcijańskiej, do wyrobienia charakteru i sumienia katolickiego ... powinniście dołączyć szczegółowe i gruntowne wykształcenie, oparte na filozofii chrześcijańskiej”, „Musimy się kształcić!”, Młoda Polka, nr 10, 1937, 143; „Nad czym radziłyśmy 20 listopada w Poznaniu”, Doniesienia Katolickiego Stowarzyszenia Kobiet, nr 12, 1938, 157.

39 „Sprawy związkowe. Kurs oświatowy”, Gazeta dla Kobiet, nr 1, 1925, 2. Szczególny segment pracy edukacyjnej przynależał do kadry zarządczej i urzędniczej, do której były skierowane propozycje nauczania trybu kierowania zespołami ludzkimi, budowania pozycji szefa zespołu. Ponadto kursy specjalne dedykowano paniom planującym podjęcie pracy sekretarki czy skarbniczki, zob.: „Kurs dla prezesek, sekretarek, skarbniczek”, Głos Polek, nr 17, 1923, 4.
} 
i prelekcji znajdowały się sprawy katolickiego nauczania, ideologii stowarzyszeń katolickich, metodyki pracy w środowisku kobiecym. Służyły pogłębianiu myśli katolickiej, tworzeniu miejsca współpracy zawodowej (przykładowo ukierunkowanie pracy na nauczycielki), propagowaniu różnego rodzaju postaci apostolstwa świeckiego, w którym aktywistki ruchów katolickich były animatorkami działań na rzecz społeczności miejscowej ${ }^{40}$. Nadzwyczajnym typem kursów stały się praktyczne działania edukacyjno-wychowawcze na rzecz przygotowania do wojny. Wzmożenie zainteresowania nastapiło w latach 1938-1939 wraz $z$ narastaniem atmosfery wojennej i umacnianiem doktryny obronnej państwa. Uzasadnieniem była liczebność oraz zaangażowanie kobiet: „Hasłem dnia dzisiejszego jest: każda kobieta i dziewczyna - a jest nas około 10 milionów w Polsce - musi przejść przez kursy ... samoobrony"41. Namawiano je do wstapienia w szeregi pomocniczej służby wojskowej, organizowania cywilnej służby zastępczej, uczestniczenia w działaniach „pogotowia społecznego”, obejmujacego ćwiczenia praktyczne z zakresu obrony przeciwgazowej, ratownictwa, pożarnictwa i innych zagrożeń wynikających $z$ ataku nieprzyjaciela. Zachęcano do poznawania form samopomocy społecznej, polegającej na utrzymaniu porzadku na terytorium okupowanym przez wroga. Kobietom przeznaczono zadania w zakresie opieki nad rodzinami żołnierzy walczacych na froncie wojennym, pomocy przy ewakuacji ludzi $z$ terenów dotkniętych wojna, samopomocy aprowizacyjnej, kwaterunkowej, odzieżowej i zdrowotnej. Zalecenia dotyczyły zmiany myślenia ekonomicznego i przejścia na tory gospodarki wojennej, zwłaszcza w zakresie logistyki życia domowego. W planach znajdowało się tworzenie kobiecych lotnych zespołów fachowych, w tym gospodarczych, opiekuńczych, sanitarnych. Myślano o szczególnej roli obywatelek państwa w realizacji działań na rzecz „pogotowia moralnego", czyli szerzenia wiary w zwycięstwo Polski nad wrogiem, podtrzymywania morale ludności cywilnej, przeciwstawiania się nastrojom defetystycznym.

\footnotetext{
40 „Apostolstwo ludzi świeckich”, Niewiasta Katolicka, nr 3, 1931, 4; „Dni myśli katolickiej dla nauczycielek", Doniesienia Katolickiego Stowarzyszenia Kobiet, nr 10, 1939, 125.

41 Druhna Redaktorka, „Silne - zwarte - gotowe”, Młoda Polka, nr 7, 1939, 100; Jadwiga Roszkowska, „Kobiety w służbie Ojczyzny”, Zjednoczenie, nr 6, 1939, 90-62.
} 


\section{Obraz personalny: modele kobiecości}

W preferowanych modelach kobiecości nakładały się trzy typy tożsamości: narodowej, religijnej i płciowej, przy czym dwa pierwsze typy - tożsamość narodowa i tożsamość religijna - tworzyły nierozerwalną całość. Istnienie zbitki pojęciowej Polka-katoliczka oznaczało, że tożsamość płciowa była odsunięta na dalszy plan $\mathrm{w}$ sytuacji, gdy manifestowano uczucia patriotyczne i więź $z$ wierzeniem religijnym. Zarazem $\mathrm{w}$ katolicki paradygmat kobiecości wkomponowany był sprzeciw wobec prób zacierania różnic między kobietą i mężczyzną. Zestaw cech płciowych pojawiał się w różnych okolicznościach opisu życia społecznego, bywał też sposobnością do moralnego unieważniania społecznych skutków agresywności (zachowania rywalizacyjne $\mathrm{w}$ stosunkach prywatnych czy konflikt wojenny w stosunkach międzynarodowych), przypisywanej czynnikowi męskiemu ${ }^{42}$. Równie stereotypowe było postrzeganie dysfunkcji czynnika męskiego, podatnego na życie w rozpuście, ulegającego nałogom w postaci uzależnienia od alkoholu czy nikotyny - w tym wypadku zwracano uwagę na kontrolną rolę czynnika kobiecego ${ }^{43}$. $Z$ wypowiedzi publicystycznych przebijało przekonanie, że mężczyzna mógł ulegać słabościom i okazywać niedostatki charakteru, ale towarzysząca mu partnerka (żona, matka, siostra) musiała wykazać się mocna osobowościa, czerpiąc siłę $z$ wiary religijnej. Na tym tle działaczka katolickiego stowarzyszenia kobiecego szczególnie powinna być niezłomna w pracy dla dobra wspólnego Polski oraz emanować skromnością i powściagliwością w życiu codziennym. Przygotowywała się do spełnienia wizji ujętej słowami: „Sprawiedliwość i miłość podstawą Królestwa Bożego na ziemi" ${ }^{44}$.

Koncentracja publicystyki prasowej na członkiniach ruchów katolickich świadczyła o dostrzeżeniu znaczenia komponentów mięk-

\footnotetext{
42 Ruchy katoliczek opowiadały się za pokojowym rozstrzyganiem konfliktów, jednak w warunkach narastania atmosfery wojennej w prasie pojawiały się akcenty wojowniczości i aprobaty siłowych rozwiazań spraw polskich. W 1938 r. czytelne było udzielenie poparcia władzom państwowym Polski w sprawie zajęcia Zaolzia, zob. „Jak kobiety walczyły o Śląsk za Olza”, Gazeta dla Kobiet, nr 11, 1938, 136.

43 Kobiety zasilały szeregi ruchu abstynenckiego, który przynależał do istotnych komponentów aktywności działaczek katolickich, zob.: Młoda Podhalanka, „Młoda Polka w walce z alkoholizmem”, Młoda Polka, nr 2, 1931, 21; B. St. [Bożena Stelmachowska], „Cyfry, które mówią. Przyczynek do walki z demoralizacją, Gazeta dla Kobiet, nr 25, 1924, 2-3.

44 Zofia Roszkówna, „Kwadrans ewangeliczny. Sprawiedliwość i miłość podstawą Królestwa Bożego na ziemi”, Zjednoczenie, nr 3, 1938, 40.
} 
kich w organizacji społecznej. Panie, przynależąc do stowarzyszeń, godziły się na rozmaite dolegliwości, takie jak: podporządkowanie kierownictwu ruchu, udział w zebraniach organizacyjnych, prowadzenie czynnej działalności, niekiedy też towarzyszył temu wkład finansowy, przykładowo, zwiazany $z$ czytelnictwem prasy. W zamian miały otrzymywać liczne gratyfikacje w postaci przekonania o: (1) zapewnieniu bezpieczeństwa moralnego sobie i rodzinie, (2) istnieniu jednomyślności wewnątrzorganizacyjnej, (3) utrwalaniu pożądanych cech wspólnych katoliczek, (4) kreowaniu pozytywnych obrazów Polek w otoczeniu społecznym ${ }^{45}$. Ponadto prasa dażyła do wytworzenia czy utrwalenia poczucia wyższości moralnej członkiń grupy, które miały (bądź chciano, żeby miały) cechy osobowości silnych, dojrzałych, świadomie wypełniających obowiązki patriotyczne identyfikowane ze służebnością wobec interesów katolickich. Istotnym wątkiem, wkomponowanym $\mathrm{w}$ kwestię motywowania do działalności w ruchu katoliczek było zagadnienie przywództwa indywidualnego i zbiorowego, legitymizowanego przez narodowość i wierzenie religijne. Przez cały okres dwudziestolecia międzywojennego w prasie dla katoliczek klarownie prezentowano konieczność wytwarzania i utrwalania jedności ruchu kobiet w sferze wspólnoty światopoglądowej. Członkinie ruchu miały możliwość uzyskania satysfakcji z pracy dla dobra wspólnego. Przynależność organizacyjna dawała im szacunek otoczenia społecznego, bezpieczeństwo działania, status środowiskowy w strukturze społecznej. Publicystki wyrażały zdanie, że katolickie ruchy kobiet służyły artykulacji rozumnego współczucia, sprawiedliwości, poszanowania godności ludzkiej. Były grupowym głosem zrozumienia dla ludzi i ich potrzeb, szczerości i bezinteresowności, zaufania dla kierownictwa organizacyjnego i aprobaty kierunku pracy społecznej. Wreszcie członkinie ruchów miały poczucie spotykania się z sacrum, którego potrzebowano w życiu prywatnym i w działalności publicznej. Nieodłącznym składnikami personalnego obrazu ruchu kobiet były zapał i entuzjazm objawiane przy wykonywaniu zadań.

W czynnościach komunikacyjnych istotne było pokazywanie wybitnych Polek: „Mamy je na każdym polu, czy to jako święte, czy to jako bohaterskie obywatelki, żony i matki, czy jako poetki i pisarki, w ostatnich czasach nawet i uczone. Obowiazkiem na-

45 Zofia Rzepecka, „Solidarność i karność podstawa pracy organizacyjnej”, Zjednoczenie, nr $12,1933,182$. 
szym jest znać życie i dzieła takich Polek, a znając je starać się je naśladować" ${ }^{\prime 6}$. W deklaracjach redakcyjno-publicystycznych artykułowana była wola przyuczania czytelniczek do odwzorowywania pożądanych postaw i zachowań. Szczerze o planach edukacyjno-wychowawczych napisały redaktorki miesięcznika „Młoda Polka”, gdy ogłaszały, że ,jednym z zadań "Młodej Polki" jest zapoznanie druhen $z$ dzielnymi kobietami polskimi, działającymi we wszystkich dziedzinach życia" ${ }^{47}$. Tworzono obraz kobiecej podmiotowości Polki i katoliczki, która miała być przygotowana do podejmowania obowiązków narodowych i religijnych. Preferencje poznawcze redukowano do spraw zwiazanych $z$ wiedza na temat cech pożądanych przy wykonywaniu ról społecznych. Publicystki kodowały dane na temat oczekiwanych postaw i zachowan. Stosowały klasyfikacje czynów poddawanych prasowej ocenie oraz wprowadzały kategorie umożliwiające optymalizowanie procesu rekonstrukcji obrazu rzeczywistości społecznej.

Na łamach prasy występowały dwa współzależne wyobrażenia uczestniczek ruchów katoliczek, wkomponowujące się w paradygmat kobiecości. W jednej grupie obrazów preferowano wyobrażenie kobiety pracowitej, sumiennej, troskliwej, rozumnie ugodowej, ustępliwej i posłusznej oraz świadomej swojego znaczenia w życiu narodu. W ten model kobiecości Polki-katoliczki wkomponowane były archetypiczne cechy Matki-Polki, skoncentrowanej na sprawach domu, męża, dzieci, rodziny i w ten sposób uczestniczącej w życiu narodu. Idealizacja macierzyństwa była oczywista $z$ powodów religijnych i historycznych, związanych $z$ doświadczeniem życia w niewoli politycznej, pod zaborami, w trakcie działań wojennych i okupacji: „Matka, to złota istota. ... Pod jej błoga opieka dziecko nasyca się szlachetna polskościa, przesiąka wiara w jednego Boga"48. W tym wypadku akcentowano znaczenie matki silnej, bezkompromisowej, wykazującej „chrześcijańska odwagę" i sprawiajacej, że w młodym pokoleniu dojdzie do utrwalenia "fundamentu prawdziwie religijnego i moralnego" 49 . W swietle publicystycznych przekonań kobieta mająca "silną rękę i miłe usposobienie” była

\footnotetext{
46 „Wybitne kobiety polskie”, Kobieta Polska, nr 12, 1918, 3.

47 Janina Tokarska, „Ta, która pokochała pokrzywdzonych i pracę”, Młoda Polka, nr 10, 1937,152 .

48 „Jubileusz Niewiast Katolickich w Jabłonkowie”, Niewiasta Katolicka, nr 7, 1931, 2; Z. W-ska, „Ku uzdrowieniu rodziny (referat dla stowarzyszeń)”, Zjednoczenie, nr 1, 1934, 4-6. 49 „O dobrej matce”, Niewiasta Katolicka, nr 6, 1931, 2.
} 
najlepsza wychowawczynią ${ }^{50}$. Wykazywała oczekiwane cechy osobowe, bowiem „najmilsza Panu Bogu jest pokora - pokorne serce, które wie, że miłość ludzka w stosunku do miłości Bożej jest zawsze niedoskonała i dlatego ustawicznie coraz bardziej stara się kochać Boga, pokorny umysł, który wie, że zdolności jego sa ograniczone, więc Bożej mądrości ufa, nie sobie, pokorna wola, która zna słabość i ułomność natury ludzkiej, więc Boskich przykazań i praw, słucha, a ludzkie prawa i polecenia Boskiej nauce poddaje" ${ }^{51}$. Ceniona publicystka Maria Czeska-Mączyńska pouczała, że

w kobiecie pięknej można się do szaleństwa zakochać, ale gdy piękna nie uzupełnia dobroć, to miłość tak szybko mija, jak szybko powstała, bowiem ukochać na całe życie można jedynie kobietę dobra. Matkę piękna, wspomina się z przyjemnościa, jak piękną lalkę, która nam uprzyjemniała dzieciństwo, matkę rozumna wspomina się z duma, ale kocha się tylko matkę dobra. Więc jeżeli chcesz być szczęśliwa kobieta, kształć w sobie dobroć, rozwijaj ja w sobie, budź, bo śpi ona zawsze w ludzkiej duszy i jak owa królewna $z$ bajki obudzenia czeka. Staraj się być dobra zawsze i dla wszystkich, a dasz szczęście trwałe i weźmiesz je ${ }^{52}$.

Duch umoralnienia aktywistek społecznych był oczywisty, a świetnie dobrane słowa, tworzace sugestywne frazy językowe, miały przynieść szczególne rezultaty związane z umacnianiem „niewieścich cnót".

W drugiej grupie wyobrażeń kobiet istniał niestereotypowy wizerunek Polki-katoliczki, aktywnej, niepokornej, zaangażowanej w życie społeczne, oddanej interesom narodowym i religijnym, gotowej do przekraczania granic domostwa i rodziny, żeby realizować cel nadrzędny w postaci utrwalania polskości i katolicyzmu. Widoczny był sprzeciw wobec schematycznego oglądu cech kobiecych takich, jak: bierność, bezmyślna uległość, egzaltowana emocjonalność, łatwowierność, neurotyczność. Udział w ruchu katoliczek miał skłaniać do refleksji nad sposobami przezwyciężenia ludzkich słabości i budowania podwalin pod głęboka, intensywna i spójna pracę edukacyjna, żeby wytwarzać niezłomne indywidualności. W tekstach prasowych przewijały się kwestie motywacji i zaangażowania kobiet w pracę społeczna, stylów przywództwa w śro-

50 „Jubileusz Niewiast Katolickich w Jabłonkowie”, 4.

51 „Wnioski z odczytu”, Materiał Pomocniczy na Zebranie Kółka Matek, nr 3, 1939, 3.

52 [Bez tytułu], Gazeta dla Kobiet, nr 2, 1928, 13. 
dowiskach kobiecych, metod zarzadzania zastępem społecznic, przebiegu procesu podejmowania decyzji o doniosłości wewnatrz organizacji i poza nią. $Z$ publicystycznych przekazów wyłaniał się obraz liderek, które były dzielne, odważne, silne, ale też emanowały życzliwością i wyrozumiałością dla uczestniczek ruchu. Potrafiły rzeczowo reprezentować interesy katoliczek na forach krajowych i międzynarodowych, gdy ich zdecydowany głos wpływał na decyzje w sprawach rodziny i jej kondycji moralnej i materialnej ${ }^{53}$. Mobilizowały do pracy społecznej, wyznaczały zadania, które obejmowały sprawy ujęte w szerszym kontekście celów narodowych i religijnych. Zarazem wyrażany był sprzeciw wobec zjawiska deprecjacji kobiet w życiu społecznym i upowszechniania negatywnego stereotypu cech kobiecych. Bożena Stelmachowska na łamach "Gazety dla Kobiet” piętnowała zawartość produktów kultury popularnej, w tym szczególnie kinematografii. Analizie poddała druki reklamowe filmów wyświetlanych w Polsce. W jej interpretacji przekaz reklamowy, zmierzając do uatrakcyjnienia treści, sięgał do negatywnych wyobrażeń kobiet. Przywołała tytuły filmów oraz frazeologię służąca opisowi fabuły filmowej w rodzaju „Dzieje kobiety upadłej”, „Niewolnica miłości”, „Szalone kobiety”, dowodząc, że produkcje kinowe służyły propagowaniu obrazu awanturnic, lekkomyślnych pań, żądnych przygód kokietek, co spuentowała sarkastycznym stwierdzeniem: „Patrzeć i podziwiać. Takiego filmu jeszcze nie było - hipnotyzuje wprost publiczność!"54. Konkluzja była przejrzysta: „Nie dziw, że młodzież szerokich mas nie ceni sobie uwag matki, za nic ma siostrę, pogardza kobietą, która nabywa znaczenia dopiero jako zabawka w jej rękach, lecz nie dorasta do miana człowieka, towarzysza, przyjaciela, równego sobie oraz istoty, której należy

\footnotetext{
53 „Obrona rodziny przez socjologię i biologię”, Kuźniczanka, nr 6, 1932, 93; „Matka Dobrej Rady”, Kuźniczanka, nr 2, 1933, 25-28; „Z nauk śp. Generałowej Jadwigi Zamoyskiej. O naszych obowiązkach względem duchowieństwa”, Pisemko Kuźniczanek, nr 7-8, 1930, 68-71.

54 B. St. [Bożena Stelmachowska], „O cześć kobiety”, Gazeta dla Kobiet, nr 17, 1924, 1. Publicystka nie wahała się sformułować opinii, że „linia kobiecego ciała w sztuce nikogo nie gorszy, jeżeli układa się szlachetnie i służy pięknu, które jest jej celem”. Dezaprobowała sytuację, w której dochodziło do uprzedmiotowienia kobiety dla celów komercyjnych, służących interesom „całego konsorcjum ludzi lubiących szybko i pewnie, mniejsza o to, czy moralnie dochodzić do fortuny”. Powtarzały się zastrzeżenia do działań „kalejdoskopu, podkasanej muzy, pornografii”, które niszczyły „rdzeń polskości i jądro polskich dusz”. Apelowano: „Krzywdzicieli dusz, studzicielki serc wraz z ich obrzydliwą produkcją, krasomówcza, literacką, kino-teatralną skażmy na wygnanie!”, Czesława Wolniewiczówna, „Zwierciadło”, Gazeta dla Kobiet, nr 2, 1925, 4-5.
} 
się szacunek i stosowanie rycerskich form"55. O wspomniany wyżej egalitaryzm płciowy należało walczyć, dlatego Stelmachowska odwołała się do solidarności kobiet i zachęcała do „wystapienia lig kobiecych ku obronie czci kobiecej"56.

Dla odwzorowania cech niezbędnych „feministkom narodowym" stosowana była technika prezentacji kilku typów kobiecych, w których widziano ideały potrzebne do wychowywania działaczek katolickich. Typ pierwszy tworzyły „ciche bohaterki”, czyli aktywistki słabo znane szerszemu ogółowi, o których więcej podawano informacji dopiero wówczas, gdy zmarły, a prasa zadbała o pamięć o ich osiagnięciach. $Z$ nekrologów i pośmiertnych wspomnień czytelniczki dowiadywały się o cenionych członkiniach katolickiego ruchu katoliczek, jak Maria Beckerowa czy Agnieszka Gond. Pochodziły $z$ różnych warstw społecznych, miały różne zasoby finansowe (Beckerowa była zamożna), środowisko aktywności społecznej (Beckerowa działała w Inowrocławiu i okolicy, Gond prowadziła pracę społeczna głównie w poznańskim środowisku kolejarskim), odmienny stan cywilny (Beckerowa była wdowa), różniła je nawet długość życia (Beckerowa zmarła w wieku 73 lat, natomiast Gond - 36 lat). Łaczyła je pasja do pełnej oddania pracy dla środowisk wykluczonych $z$ powodu biedy materialnej, bezrobocia, bezdomności. Agnieszka Gond, aktywna działaczka zwiąków zawodowych, była przewodnicząca Sekcji Pań przy Polskim Związku Kolejarzy (PZK), stała się inicjatorka powołania Centralnej Sekcji Pań przy PZK, a nade wszystko znano ja jako społecznicę, która organizowała wszechstronna pomoc dla kolejarskich sierot. Miała „niezwykłe zalety i zasługi w pracy społecznej, dla polepszenia i zabezpieczenia znośnego bytu ogółu pracowniczek, która ponadto świeciła przykładem Kobiety Polki"57. Maria Beckerowa ufundowała dla ubogich dzieci grunt pod inowrocławskie „Przytulisko”, ponadto czynnie włączyła się w działalność Rady Wyższej Towarzystwa Pań św. Wincentego à Paulo. „W obcowaniu $z$ ludźmi zawsze uprzejma, uczynna i serdeczna, nie zrażała się do sprawy doznanymi przykrościami, uważając je za nieodłączne od wszelkiej pracy społecznej”58.

55 B. St., „O cześć kobiety”, 2.

56 Ibidem, 1.

57 „Wspomnienie pośmiertne”, Gazeta dla Kobiet, nr 2, 1925, 5; „Śp. Agnieszka Gond”, Gazeta dla Kobiet, nr 1, 1925, 3-4.

58 Zofia Rzepecka, „Śp. Maria Beckerowa”, Doniesienia Katolickiego Stowarzyszenia Kobiet, nr 11, 1938, 142. 
Wchodziła w skład zarządów wpływowych organizacji ruchu kobiet, a więc Związku Kobiet Pracujacych i Zjednoczenia Towarzystw Kobiecych.

Typ drugi tworzyły działaczki, które łączyły aktywność organizacyjna $z$ redagowaniem prasy, pisaniem tekstów, budowaniem interakcji między aparatem nadawczym (centrale stowarzyszeń) i odbiorczym (czytelniczki). Ceniły kanał przekazu, jakim była prasa. Ich zaangażowanie $\mathrm{w}$ sprawne i staranne opracowywanie poszczególnych numerów pism stawało się dowodem funkcjonalnego wymiaru zawodowej pracy kobiet. Sylwetki Marii Czeskiej-Maczyńskiej, Anny Orłowskiej, Czesławy Wolniewiczówny, Felicji Żurowskiej stanowiły potwierdzenie istnienia „feministek narodowych”, które - bez manifestacyjnego domagania się praw płci - budowały klimat społecznego przyzwolenia dla pełnego i zróżnicowanego zaangażowania kobiet w sprawy publiczne. Potwierdzały umiejętności $\mathrm{w}$ pracy strukturalno-propagandowej, prowadzonej ze znawstwem, jak to czyniła Orłowska, która dbała o sprawy organizacyjne, oświatowe i wychowawcze, troszcząc się o poziom życia religijnego członkiń. Przygotowywała program pracy rocznej, urządzała kursy edukacyjne, organizowała odprawy okręgowe i wizytowała oddziały terenowe. Jej członkostwo w zarządzie KSMŻ w Poznaniu owocowało udziałem w obradach i posiedzeniach komisji programowej. Pilnowała wydawania komunikatów, odezw i druków sprawozdawczych. Pisała teksty krótkie, skoncentrowane na informacyjno-propagandowej stronie pracy formacyjnej wśród młodego pokolenia ${ }^{59}$. Cieszyła się sympatia czytelniczek okólnika „Przewodnik Młodzieży Żeńskiej”, czemu dawała wyraz, publikując podziękowania za życzliwość i wsparcie w pracy organizacyjnej ${ }^{60}$. Wysoko cenione były publicystki, które wykazywały uzdolnienia literackie, w równym stopniu zajmując się literatura piękną i twórczością użytkową. W prasie dla katoliczek upowszechniana była twórczość Czeskiej-Mączyńskiej, która pisała opowiadania biblijne, powieści historyczne i młodzieżowe, wydała też poradnik młodej matki utrzymany w postaci zapisków memuarystycznych. Ponadto wykazywała

\footnotetext{
59 Anna Orłowska, „Ze Zjazdu w Wejherowie”, Przewodnik Młodzieży Żeńskiej, nr 1, 1927, 6-7; eadem, „Tegoroczny Zjazd Delegowanych”, Przewodnik Młodzieży Żeńskiej, nr 3, 1929, 25-26; „Sekretariat Generalny Stowarzyszenia”, Przewodnik Młodzieży Żeńskiej, nr 5, 1936, 5; zob. Anna Faber-Chojnacka, Czasopisma krakowskie dla dzieci i młodzieży w dwudziestoleciu międzywojennym, (Kraków: Wydawnictwo Naukowe WSP, 1995), 35, 97.

60 Anna Orłowska, „Podziękowanie”, Przewodnik Młodzieży Żeńskiej, nr 8, 1936, 2-3.
} 
predyspozycje dramatopisarskie, tworzyła poematy liryczne oraz napisała słowa do muzyki kościelnej. Popularyzowana była postać Wolniewiczówny, „młodej, dzielnej i energicznej” działaczki, która umiała przyciagać uwagę czytelników. Publikowała dramaty religijne (przykładowo Gdzie jesteś, Panie), a także dzieła literackie przeznaczone do bieżącego wykorzystania w pracy członkiń organizacji katolickich, szczególnie przy okazji okolicznościowych spotkań organizacyjnych. Sporządzała jednoaktówki przeznaczone na uroczystości świąteczne, żeby łatwo można je było zaadaptować do warunków świetlicowych $^{61}$. Podobnie doceniano dorobek Żurowskiej (obrazki sceniczne Perły Najświętszej Panienki), zachęcając do lektury jej dzieł, żeby pogłębić życie duchowe pañ ${ }^{62}$.

Wreszcie trzeci typ - w hierarchii wychowawczej zajmujacy najwyższą pozycję - zawierał sylwetki wybitnych kobiet, które wpłynęły na najnowszą historię Polski. Szczególne miejsce przyznawano Elizie Orzeszkowej, propagatorce równouprawnienia kobiet, oświaty dla ludu, wzmocnienia ekonomicznego narodu. Wysoko oceniano jej umiejętność wykorzystania pozytywistycznego programu naprawy społeczeństwa i pogodzenia go $z$ „chrześcijańska wiarą w zwycięstwo dobra, choćby ono na chwilę zostało zwyciężone przez zło"63. Przypominanie i upowszechnianie wiedzy na temat dorobku pisarskiego Orzeszkowej miało zwrócić uwagę na przebieg działań służących sformowaniu ruchu walki o dostęp kobiet do nauki, do pracy, do decydowania o zamążpójściu - w tym wypadku wykorzystany został motyw biograficzny z młodości pisarki, kiedy „nikt nie pytał jej, jakie ma plany na przyszłość. $Z$ góry za najlepszą i jedyną karierę dla kobiety uważano zamążpójście. Kobieta miała zamkniętą drogę do pracy. Nikt jej zreszta do pracy nie przygotowywał"64. Posłużenie

\footnotetext{
61 Czesława Wolniewiczówna, „W dniu wigilijnym. Jednoaktówka”, Młoda Polka, nr 11, 1921, 125-128; „Pierwszy zlot młodzieży żeńskiej w Częstochowie”, Goniec Częstochowski, nr 72, 1924, 2; Halina Zaorska, „Wieczory świetlicowe”, Zjednoczenie, nr 12, 1938, 193.

62 Felicja Żurowska, „Pierwsze ofiary. Obrazek sceniczny”, Młoda Polka, nr 10, 1924, 194196. Korzystała też z dostępu do innych mediów masowych. Przykładem były jej pogadanki radiowe w rozgłośni poznańskiej, w której wypowiedzi dotyczyły m.in. kwestii ochrony młodzieży przed zagrożeniem alkoholizmem, Maria Romana Dediowa, Czy nasze dzieci będa szczęśliwe? (Wykład wygłoszony przez Radio Poznańskie 2 II 1930 r.), Czesława Wolniewiczówna, Idea abstynencka w Stowarzyszeniach Młodzieży Polskiej (Wykład radiowy wygłoszony w Poznaniu 6 II 1930 r.), (Poznań: Katolicki Zwiazek Abstynentów, 1930), 5-7.

63 Janina Tokarska, „Ta, która pokochała pokrzywdzonych i pracę”, Młoda Polka, nr 10, $1937,153$.

64 Ibidem, 153-154. Motyw pracy zarobkowej celem utrzymania siebie, a w wypadku niezaradności męża lub wdowieństwa, nie mógł przesłonić obowiązku katoliczki „wstąpienia
} 
się informacja zaczerpniętą z życiorysu Orzeszkowej miało zwielokrotnione przesłanie, w tym przynajmniej dwa szczególne, mające natychmiastowy efekt perswazyjny. Po pierwsze, pozwalało na pokazanie losu kobiet podlegających presji społecznej w kwestii życia osobistego. Po drugie, służyło wyjaśnieniu czy usprawiedliwieniu decyzji pisarki o odejściu od męża, $z$ którym związek był następstwem presji rodziny. Postać Orzeszkowej, podażającej własną droga życia i twórczości literackiej bez oglądania się na konwenanse, dała szansę na upowszechnianie obrazu kobiety silnej, kreatywnej, odnoszacej sukcesy, ponieważ była oddana działalności dla dobra wspólnego. Dydaktyczny walor artykułu prasowego wybrzmiał wyraźnie, gdy jego autorka zwróciła uwagę na istotny element spuścizny artystycznej, który „tę wielka pisarkę czyni szczególnie bliska nam, druhnom KSMŻ. ... Orzeszkowa czci pracę codzienna, szara, fizyczna, $z$ jaka każda $z$ nas przez całe życie się styka"65. Bezpośrednie zwrócenie się do młodych adeptek ruchu kobiet świadczyło o gotowości kształtowania postaw pochwalajacych samodzielność kobiet przy decydowaniu o wyborze drogi życiowej we wspomnianej już wcześniej dwoistości obrazów katoliczek.

Ponad nadmienionymi typami kobiecych wzorców pokazywano postaci przywódczyń katolickich ruchów kobiecych na świecie i w Polsce. Odbiorczyniom prasy została przybliżona postać Christine de Hemptinne, która od chwili powstania w 1926 r. Młodej Unii w ramach Międzynarodowej Unii Katolickich Związków Kobiecych stała na jej czele ${ }^{66}$. Na łamach miesięcznika „Młoda Polka” prezentowano jej cechy jako przywódczyni uosabiającej typ „współczesnej apostołki”, która „jest mężna co dzień oraz w dniach wiel-

w święty związek małżeński”, zalecanego na łamach „Niewiasty Katolickiej”. Zarazem widziano możliwość wystapienia sytuacji, w której kobieta nie jest zainteresowana zamażpójściem, wówczas proponowano następujące rozwiazanie: „Wykształcone katoliczki, którym nie uśmiecha się ślubny wieniec, zastępują swe niewieście powołanie macierzyństwem duchowym, polegajacym na świadczeniu dla potrzebujących w społeczeństwie takich usług, które zwykle spełnia niewiasta w rodzinie”, „Dwojakość w powołaniu żeńskim”, Niewiasta Katolicka, nr 1, 1932, 2.

65 Janina Tokarska, „Ta, która pokochała pokrzywdzonych i pracę”, Młoda Polka, nr 10, $1937,154$.

66 Christine de Hemptinne (1895-1984) należała do znanej arystokratycznej rodziny belgijskiej, założycielka, kierowniczka i honorowa przewodnicząca światowej federacji stowarzyszeń dziewcząt katolickich oraz przewodnicząca Związku Kobiet na rzecz Akcji Katolickiej. Zajmowała się wydawnictwami katechetycznymi, opracowała dzieje Katolickiego Stowarzyszenia Młodzieży Żeńskiej w Belgii, zob. Christine de Hemptinne, L'Association Catholique de la Jeunesse Belge Féminine, (Paris: Librairie Giraudon, 1930). 
kich wystapień" ${ }^{67}$. Zwracano uwagę na poświęcenie dla dobra ogółu i wyrzeczenie dla sprawy „szerzenia królestwa Chrystusowego na ziemi". W opisie jej sylwetki przewijały się wzmianki o wypełnianiu misji, o wiedzy i zapale, o pokonywaniu trudności i wygrywaniu ze słabościami ludzkimi. Liderka ruchu kobiet była nieustannie czynna, dawała dowody nieugiętości w procesie upowszechniania „ideologii braterstwa Chrystusowego". W tekście prasowym wzmiankowano o podróżach po całym świecie celem szerzenia ideałów katolickich, o tym, że „zna ja Ameryka Południowa, gdzie w przeciagu trzech miesięcy wygłosiła 240 wykładów, odbyła niezliczoną ilość konferencji, zainicjowała parę katolickich szkół społecznych, zreorganizowała pracę katolicka”68. Na temat katolickiego ruchu kobiet $\mathrm{w}$ Belgii oraz tamtejszych form instytucjonalnej działalności kobiet pisano w prasie wielokrotnie. Zwiazki z Belgia miały wymiar światopoglądowy oraz osobowy, ponieważ biograficznym doświadczeniem części aktywistek była obecność w środowisku Belgijek. Dobry przykład dla czytelniczek stanowiła Felicja Żurowska, która w wolnej Polsce jako młoda osoba (rocznik 1896) podjęła intensywną działalność w młodzieżowych organizacjach katolickich w Poznaniu. Współpracowała $z$ wielkopolskim duchowieństwem, zdobywając wiedzę o metodyce pracy wśród młodego pokolenia. Odebrała zawodowe wykształcenie rolnicze, ale jej pasją była działalność edukacyjna i wychowawcza. W celu pogłębienia praktycznej wiedzy na ten temat udała się właśnie do Belgii, co było możliwe dzięki uzyskanemu przez nią stypendium ufundowanemu przez Księgarnię św. Wojciecha. Pozostawała pod wpływem idei „głoszenia ewangelii ubogim", doceniając, że jej propagator ksiądz (późniejszy kardynał) Joseph Léon Cardijn założył Jeunesse ouvrière chrétienne (Katolicka Młodzież Pracująca) ${ }^{69}$.

Autorytet kobiet zasłużonych dla ruchu społecznego wzmacniał czynności perswazyjne służące uświadomieniu rangi działań Polek i katoliczek. W poczuciu erozji dotychczasowej tradycji i obyczajności czy przyspieszonego modyfikowania stratygrafii społecznej publicystki prasowe wyrażały potrzebę chronienia „odwiecznych" podstaw życia społecznego, utrwalania wiedzy o wybitnych

67 Halina Doria-Dernałowicz, „Krystyna de Hemptinne”, Młoda Polka, nr 10, 1937, 149.

68 Ibidem, 148.

69 Andrzej Targosz, „Formy duszpasterstwa biblijnego młodzieży. Na kanwie działalności Felicji Żurowskiej”, Ruch Biblijny i Liturgiczny, nr 6, 1985, 390. 
Polkach, patriotkach i społecznicach, zasłużonych dla religii, narodu i państwa. Obrazowanie kobiet odbywało się według modelu tradycyjnego $z$ obowiązkowym motywem żony, matki, opiekunki domu („kapłanki ogniska domowego”). Jednakże wskutek ukazywania sylwetek działaczek ruchu kobiet, uczestniczek stowarzyszeń, animatorek życia społecznego, poszerzała się przestrzeń, w której funkcjonowała obywatelka RP, mająca prawa polityczne, świadoma własnej roli społecznej, współwystępująca w procesie decydowania o sprawach prywatnych i państwowych. Tym samym wykraczała poza granice życia wyznaczonego zwyczajami krzywdzącymi kobietę, łamała konwencję społeczeństwa patriarchalnego, ale bez formalnego sprzeciwu wobec jego zasad. Obraz działaczki ruchu katoliczek był wyobrażeniem promotorki umiaru i rozwagi, propagatorki zmian społecznych o znamionach łagodnej i kontrolowanej ewolucji, której sensem było systemowe wyeliminowanie zagrożenia porządku wyznaczonego normami katolicko-narodowymi.

\section{Zakończenie}

Rekonstrukcja obrazu ruchów kobiet odbywała się w warunkach diagnozowania stanu prasy dla katoliczek i tematycznie dotyczyła zagadnienia wiary religijnej, sytuacji Kościoła, żywotów świętych, działalności ewangelizacyjnej, zagrożeń duchowych z powodu laicyzacji życia społecznego. Dla przeciwdziałania wpływom ośrodków destrukcji zwracano baczną uwagę na rodzinę, szkołę, środowisko pracy, politykę i media, we wszystkich sferach życia społecznego odnajdując obecność kobiet i wskazując na rangę ich działania zgodnie $z$ nauczaniem Kościoła. Ideał wychowawczy zawierał obraz katoliczki świadomej swoich obowiązków. Skuteczność działań integracyjnych wokół katolickiego systemu wartości była uzależniona od stopnia obecności wierzenia religijnego przy wyjaśnianiu procesów definiowania kobiecych ról społecznych oraz utrwalania, ale też ewoluowania, wyobrażeń na temat zmiennych objaśniających cechy kobiecości i męskości.

Nakładające się obrazy społecznych ruchów kobiet, skoncentrowane na działalności katoliczek, miały różną wartość i rozmaity charakter. Obrazy pozytywne pobudzały do szlachetnych zachowań społecznych, negatywne służyły wyrugowaniu słabości 
i usterek, prowadzacych do niedomagania narodu i państwa. Dlatego obraz instytucjonalny i personalny ruchów katoliczek zawierał sprzeciw wobec zjawiska próżniactwa społecznego, w którym widziano przejawy niedostatku świadomości obowiazków narodowych, państwowych, religijnych. Motyw dydaktyczny był wyrazisty: kobieta leniwa musiała wiedzieć o odpowiedzialności za zło społeczne, za przyzwolenie na stany patologiczne, za próby wprowadzenia permisywnego stylu wychowawczego, prowadzącego do nadmiaru swobody młodych ludzi, pozbawionych rygoryzmu dydaktycznego, przez co ulegajacych demoralizacji. Dla przeciwdziałania apatii, bezczynności, gnuśności konieczne było poszerzanie działalności ruchów kobiet. W prasie dla katoliczek pokazywano, jak ważne były kompetencje społeczne, umiejętność współpracy, zdolność do pracy formacyjno-strukturalnej w postaci powoływania kolejnych ośrodków pracy społecznej. Dzięki temu oczekiwano poprawy stanu polskości, pogłębienia dumy narodowej, wzmocnienia poczucia wartości Polek.

\section{Bibliografia}

\section{Źródła}

\section{Prasa}

„Doniesienia Katolickiego Stowarzyszenia Kobiet”, 1938-1939.

„Dziennik Bydgoski”, 1931.

"Gazeta dla Kobiet”, 1918-1938.

"Głos Polek", 1923.

„Goniec Częstochowski”, 1924.

„Kobieta Polska”, 1917-1918.

„Kuźniczanka”, 1932-1933.

"Młoda Polka”, 1921-1924, 1937-1939.

„Niewiasta Katolicka”, 1931-1932.

„Pisemko Kuźniczanek”, 1930.

„Posłaniec Diecezjalnego Instytutu Akcji Katolickiej”, 1939.

„Przewodnik Młodzieży Żeńskiej”, 1927-1929, 1936-1938.

„Własnymi Siłami”, 1938.

„Zjednoczenie”, 1933-1939. 


\section{Publicystyka społeczna}

A.L. [Augustyn Lipnicki]. Tak zwana „emancypacja” a chrześcijańskie stanowisko niewiasty. W dwóch częściach: krytycznej $i$ sprawozdawczej, t. 1, Część krytyczna, (Warszawa: Księgarnia Wojciecha Cithurusa, 1887).

Berkanówna, Kazimiera. Co robić? Wezwanie do pracy społecznej. Zapiski z własnych doświadczeń, (Poznań: Księgarnia św. Wojciecha, 1933).

Berkanówna, Kazimiera. O co chodzi? Kobieta w dobie kryzysu, (Poznań: Księgarnia św. Wojciecha, 1934).

Daszyńska-Golińska, Zofia. Przed jutrem. Współczesny ruch kobiecy wobec kwestii robotnic. Odczyt, (Kraków: Wydawnictwo „Krytyki", 1897).

Dediowa, Maria Romana. Czy nasze dzieci będa szczęśliwe? (Wykład wygłoszony przez Radio Poznańskie 2 II 1930 r.), Czesława Wolniewiczówna, Idea abstynencka $w$ Stowarzyszeniach Młodzieży Polskiej (Wykład radiowy wygłoszony w Poznaniu 6 II 1930 r.), (Poznań: Katolicki Zwiazek Abstynentów, 1930).

Findeisen, Maria. Kobieta katoliczka $w$ świecie wspótczesnym według „Dni Studiów” Międzynarodowej Unii Katolickich Organizacji Kobiecych $w$ Brukseli $w$ dniach 2-6 kwietnia 1937 r. Referat wygłoszony na Zjeździe Związkowym Katolickiego Zwiąku w Poznaniu, dn. 30 VI 1937, (Poznań: Katolicki Związek Kobiet, 1937).

Hemptinne de, Christine. L'Association Catholique de la Jeunesse Belge Féminine, (Paris: Librairie Giraudon, 1930).

Męczkowska, Teodora. Ruch kobiecy. Ideały etyczno-społeczne ruchu kobiecego, (Warszawa: Księgarnia Gebethnera i Wolffa, 1907).

Pruszkowski, Antoni. „Przewodnik społeczny. Dane monograficzno-orientacyjne 250-ciu polskich stowarzyszeń i związków: I. Młodzieży, II. B.[yłych] wojskowych, III. Ogólnospołecznych, IV. Kulturalno-oświatowych, V. Gospodarczych, VI. Kobiecych, VII. Akcji Katolickiej, VIII. Zw.[iązków] zawodowych, IX. Różnych", (Warszawa: Drukarnia P. Brzeziński, 1934).

„Przemówienie Wandy Pełczyńskiej”, w: Sprawozdanie stenograficzne $z 66$ posiedzenia $w$ dniu 10 lutego 1938 r. Sejm Rzeczypospolitej Polskiej, kadencja IV, sesja zwyczajna, (Warszawa: Wyd. Sejmu Rzeczypospolitej Polskiej,1938), 1. 66 [online] [dostęp: 
2.09.2021]. Dostępne w World Wide Web: http://dlibra.umcs. lublin.pl/dlibra/docmetadata?id=18179\&from=publication .

Rzepecka, Zofia. Akcja Katolicka w organizacjach kobiecych, (Poznań: Katolicki Związek Kobiet, 1935).

Rzepecka, Zofia. W służbie dobra i prawdy. Wykłady, przemówienia, listy, (Poznań: Zjednoczenie Młodzieży Polskiej, 1931).

Sołtanówna, Helena. Początki katolickiego ruchu kobiecego w Polsce, (Poznań: Ostoja, 1930).

Walewska, Cecylia. Ruch kobiecy w Polsce. Część 1 i 2, (Warszawa: Księgarnia Gebethnera i Wolffa, 1909).

\section{Opracowania}

Bauchrowicz-Tocka, Maria. „Zakonspirowane mężatki»”, czyli o ograniczeniach obyczajowych i prawnych wobec pracujących kobiet na łamach "Tygodnika Kobiety"”, w: Małgorzata Dajnowicz, Adam Miodowski (red.), Polityka i politycy w prasie XX i XXI wieku. Polityka w prasie kobiecej, (Białystok: Wydawnictwo Uniwersytetu w Białymstoku, 2019), 103-116.

Chwastyk-Kowalczyk, Jolanta. „Agitacja obywatelska przed- i powyborcza 1928 roku na łamach "Kobiety Współczesnej"”, Czasopismo Naukowe Instytutu Studiów Kobiecych, nr 1, 2019, 105-137.

Faber-Chojnacka, Anna. Czasopisma krakowskie dla dzieci i młodzieży $w$ dwudziestoleciu międzywojennym, (Kraków: Wydawnictwo Naukowe WSP, 1995).

Lechicki, Czesław. „Prasa katolicka Drugiej Rzeczypospolitej”, Kwartalnik Historii Prasy Polskiej, nr 2, 1984, 65-84.

Lepa, Adam. „Wstęp”, w: Adam Lepa (oprac.), Katalog prasy katolickiej $w$ Polsce. Stan z 31 stycznia 1994 r., (Łódź: Archidiecezjalne Wydawnictwo Łódzkie, 1994), 3-7.

Maj, Ewa. „Feminizm narodowy", czyli o kobietach w Narodowej Demokracji”, w: Maria Marczewska-Rytko, Dorota Maj, Marcin Pomarański (red.), Feminizm, (Lublin: Wydawnictwo Uniwersytetu Marii Curie-Skłodowskiej, 2015), 217-229.

Maj, Ewa. „Wzorzec kobiety w prasie dla katoliczek w Polsce międzywojennej: przypadek periodyku "Kuźniczanka" (1931-1936)", Czasopismo Naukowe Instytutu Studiów Kobiecych, nr 1, 2020, 113-139.

Michalska, Iwonna. „Rodzinne obowiazki kobiety w świetle katolickiego periodyku "Gazeta dla Kobiet" $z$ lat 1918-1938", Lubelski Rocznik Pedagogiczny, nr 1, 2020, 27-41. 
Młynarczyk, Ewa. „Tendencje nazwotwórcze w chrematonimii społecznościowej II Rzeczypospolitej (na przykładzie nazw stowarzyszeń)", Onomastica, 2019, 209-226.

„Ruch kobiet”, w: Gordon Marshall (red.), Słownik socjologii i nauk spolecznych, (Warszawa: Wydawnictwo Naukowe PWN, 2005), 287.

Targosz, Andrzej. „Formy duszpasterstwa biblijnego młodzieży. Na kanwie działalności Felicji Żurowskiej”, Ruch Biblijny i Liturgiczny, nr 6, 1985, 390-398. 